\title{
THE GLOBAL ENDODRAINAGE SYSTEM: SOME FLUID-PHYSICAL MECHANISMS OF GEODYNAMIC PROCESSES
}

\author{
G. S. Vartanyan \\ Lithosphere Strain Kinetics Inc., Toronto, Canada
}

\begin{abstract}
The article presents the main results of more than forty-year studies of the hydrogeodeformation field. We have establish some new properties of lithospheric massifs, which are clearly detectable during the periods of fast geodynamic activation (FGeDA). These processes are contrastingly manifested within the planetary megastructure the Global Endodrainage System (GEDS) of the Earth. The article discusses ideas about the conditions of formation, the specific features of functioning and the role of the asthenosphere as an essential element of the GEDS. It shows the dominant role of fluid processes that take place in the GEDS and provide the conditions for the 'maturation' of geodynamic catastrophes. The features of the formation of deformation disturbances and the dominant directions of the planetary migration of deformation impulses from the places of future catastrophic seismic events along the GEDS are considered. The regional hydrogeodeformation monitoring (HDGM) results give evidence of a close relationship between the lithospheric massifs in distant regions of the Earth: replica signals along the GDES length repeat an initial impulse originating from the area of a future seismic event. Attention is given to trigger effects that cause a seismic energy discharge at a large distance and, in some cases, can cause a cascade of earthquakes. It is proposed to create a HDGM system for monitoring of large seismic regions of the Earth.
\end{abstract}

Key words: Global Endodrainage System (GEDS); Earth fluidosphere; regional hydrogeodeformatics; HGD field of the Earth; hydrogeodeformation monitoring; earthquake 


\title{
ГЛОБАЛЬНАЯ ЭНДОДРЕНАЖНАЯ СИСТЕМА: НЕКОТОРЫЕ ФЛЮИДОФИЗИЧЕСКИЕ МЕХАНИЗМЫ ГЕОДИНАМИЧЕСКИХ ПРОЦЕССОВ
}

\author{
Г. С. Вартанян \\ Lithosphere Strain Kinetics Inc., Торонто, Канада
}

\begin{abstract}
Аннотация: В статье рассматриваются основные результаты более чем сорокалетних исследований гидрогеодеформационного поля, которые позволили установить некоторые новые свойства литосферных толщ, особенно четко проявленные в периоды скоротечной геодинамической активизации. Эти процессы контрастно прослеживаются в пределах планетарной мегаструктуры - глобальной эндодренажной системы (ГЭДС) Земли. Предлагаются к обсуждению представления об условиях формирования, специфических особенностях функционирования и роли астеносферы как важнейшего элемента ГЭДС. Показана доминантная роль флюидных процессов, которые в пределах ГЭДС обеспечивают условия «созревания» геодинамических катастроф. Рассматриваются особенности формирования деформационных возмущений и господствующие направления планетарной миграции деформационных импульсов от мест будущей сейсмической катастрофы вдоль ГЭДС. Излагаются результаты регионального гидрогеодеформационного (ГГД) мониторинга, свидетельствующие о тесной связи литосферных массивов в удаленных друг от друга регионах Земли: сигналыреплики вдоль протяженности ГЭДС повторяют первоначальный импульс, зародившийся в регионе будущего сейсмического события. Рассматриваются триггерные эффекты, вызывающие срыв сейсмической энергии на большом удалении и в некоторых случаях способные вызвать каскад землетрясений. Предлагается создание системы ГГД-мониторинга крупных сейсмоопасных регионов Земли.
\end{abstract}

Ключевые слова: глобальная эндодренажная система; флюидосфера Земли; региональная гидрогеодеформатика; ггд-поле Земли; гидрогеодеформационный мониторинг; землетрясение

\section{1. ВВЕДЕНИЕ}

Вся совокупность знаний, накопленных науками о Земле, дает основание говорить о том, что бесчисленное множество макропроцессов эволюции вещества в природе прямо или опосредованно развивается через разрушение или синтез флюидных субстанций и сопровождается многократными фазовыми переходами вещества: от жидкого к твердому и наоборот. Это особенно характерно для генезиса ранних петроминеральных образований, первичная форма которых связана с высокотемпературными реакциями в прарасплавах формирующейся планеты. В последующей, уже собственно геологической, истории развития большинство таких соединений, оказываясь в условиях, отличных от изначальных температур и давлений, меняли свой состав и облик. При этом подавляющее большинство магматических и метаморфических преобразований минеральных соединений в литосфере и тем более процессов, которые связаны с формированием огромной группы осадочных по- род, также происходит во флюидной и водной среде.

Подобные эволюции состояния больших масс пород не могут не сказываться на многих свойствах протяженных геологических объектов, начиная от изменения их несущих свойств, сопротивляемости размыву, эрозии, растворимости и кончая такими важными показателями, как упругие свойства и способность длительно противостоять внешним нагрузкам. Ниже излагаются некоторые особенности скоротечных изменений деформированного состояния крупных геологических массивов и предлагаются к рассмотрению представления о связи быстрых эволюций поля напряжений (деформации литосферы) с некоторыми глубинными флюидными процессами.

\section{2. ГИДРОГЕОДЕФОРМАЦИОННОЕ ПОЛЕ}

Масштабные исследования, нацеленные на поиск надежных предвестников разрушительных 
сейсмических событий гидрогеологическими методами, были начаты в рамках научных программ ВСЕГИНГЕО в 70-80-х годах XX века. В основе этих работ - несколько патентов на изобретения [Vartanyan, 1979a, 1979b] и научное открытие [Discoveries..., 1983]. Сущность открытия заключается в обнаружении явления глобально распространенных пульсационных изменений в гидрогеосфере, обусловленных способностью последней реагировать на изменения напряженного состояния литосферы. Эти пульсационные изменения отражают функционирование постоянно присутствующего в литосферном пространстве геофизического поля особой разновидности - гидрогеодеформационного (ГГД) поля Земли.

Исследования ГГД-поля, выполнявшиеся для изучения обнаруженного явления, первоначально охватывали геодинамически активные территории бывшего СССР, включая Россию, Казахстан, Туркмению, Узбекистан, Киргизию, Армению, Украину, Молдавию, Грузию, Азербайджан. Позже по отдельным соглашениям с геологическими службами других государств такие исследования проводились с целью изучения геодинамических процессов в Калифорнии (Соглашение о научно-техническом содружестве между Мингео CCCP и USGS), на острове Хонсю (совместные исследования ВСЕГИНГЕО, GEOS и GSJ), Дании (совместные исследования ВСЕГИНГЕО и GEOS). C 2013 г. исследования ГГДполя реализуются в Канаде корпорацией Lithosphere Strain Kinetics (LSK Inc).

Исходными данными для всех построений ГГДполя являлась информация о состоянии уровней (напоров, давлений) воды в скважинах специализированной наблюдательной сети. Съем информации в полевых условиях, как правило, выполнялся ежечасно. Последующая обработка такого материала преобразовывала «собственно гидрогеологические (гидродинамические)» данные в геомеханические характеристики среды, а использование этой информации для построения карт давало представление о деформированном состоянии изучаемого ареала в любой текущий момент времени [Vartanyan, 1979a, 1979b, 2008a, 2010; Vartanyan et al., 1985; и дp.]. Результаты этих работ характеризовали отдельные черты функционирования ГГД-поля Земли и указывали на существование прямой связи между состоянием геологической среды и проявлениями сильных землетрясений [Vartanyan, 1993, 1995, 1999, 2001, 2008b, 2015, 2016; Vartanyan et al., 1991, 1997, 2002; Christensen, 1994].

Как показали исследования, ткань ГГД-поля представляет собой совокупность короткоживущих структур деформации, которые формируют во всем объеме литосферных толщ целостное образование и проявляются в виде трехмерных пульсационно развивающихся тел с периодами существования сутки - месяцы [Vartanyan, Kulikov, 1982; Vartanyan, 1995, 1999, 2015, 2016]. Обширные литосферные толщи по своей физической природе являются своеобразным жестким панцирем, который сковывает планету снаружи. В короткие периоды, исчисляемые интервалами в несколько месяцев, этот панцирь испытывает быстрые «всплески» растяжения, связанные с изменением состояния обширных планетарных масс.

В качестве природных «меток», обеспечивающих возможность отслеживания кинетики таких превращений ГГД-поля Земли, используются размеры короткоживущих структур деформации, ограничиваемые некоторыми заранее принимаемыми изолиниями. При этом текущий размер структуры (De, тыс. км $^{2}$ ) становится фундаментальной характеристикой ГГД-поля, обеспечивающей количественные оценки геодинамических процессов, которые развиваются в реальном времени в литосферном пространстве. Так, например, деформограмма De-t и производная от нее, скорость деформационного процесса, представленная в виде соответствующих годографов ${ }^{1}$ Ve-t, дает основание для суждения о «спокойном» или геодинамически возбужденном периоде жизни изучаемого региона. Иными словами, автоматизированные построения кривых De-t (Ve-t), которые отображают скоротечные изменения состояния короткоживущих структур деформации, наряду с картами-моделями становятся инструментально фиксированными характеристиками деформированного состояния, масштабов и особенностей развития геологических массивов в реальном времени (рис. 1).

Большой объем инструментальных и феноменологических наблюдений свидетельствует о процессах воздымания крупных территорий, предваряющих будущие сильные сейсмические события. Приращение высотных отметок территории, которое поддается регистрации в масштабе реального времени, очевидно, можно рассматривать как один из весьма перспективных сейсмопрогностических показателей, для чего могут понадобиться очень плотные сети геодезических наблюдений и высокая оперативность обработки полевых измерений.

\footnotetext{
1 Годограф Ve-t дает представление о скорости изменения площади структуры деформации, то есть свидетельствует о темпах роста или вырождения короткоживущего сооружения в геологических образованиях.
} 


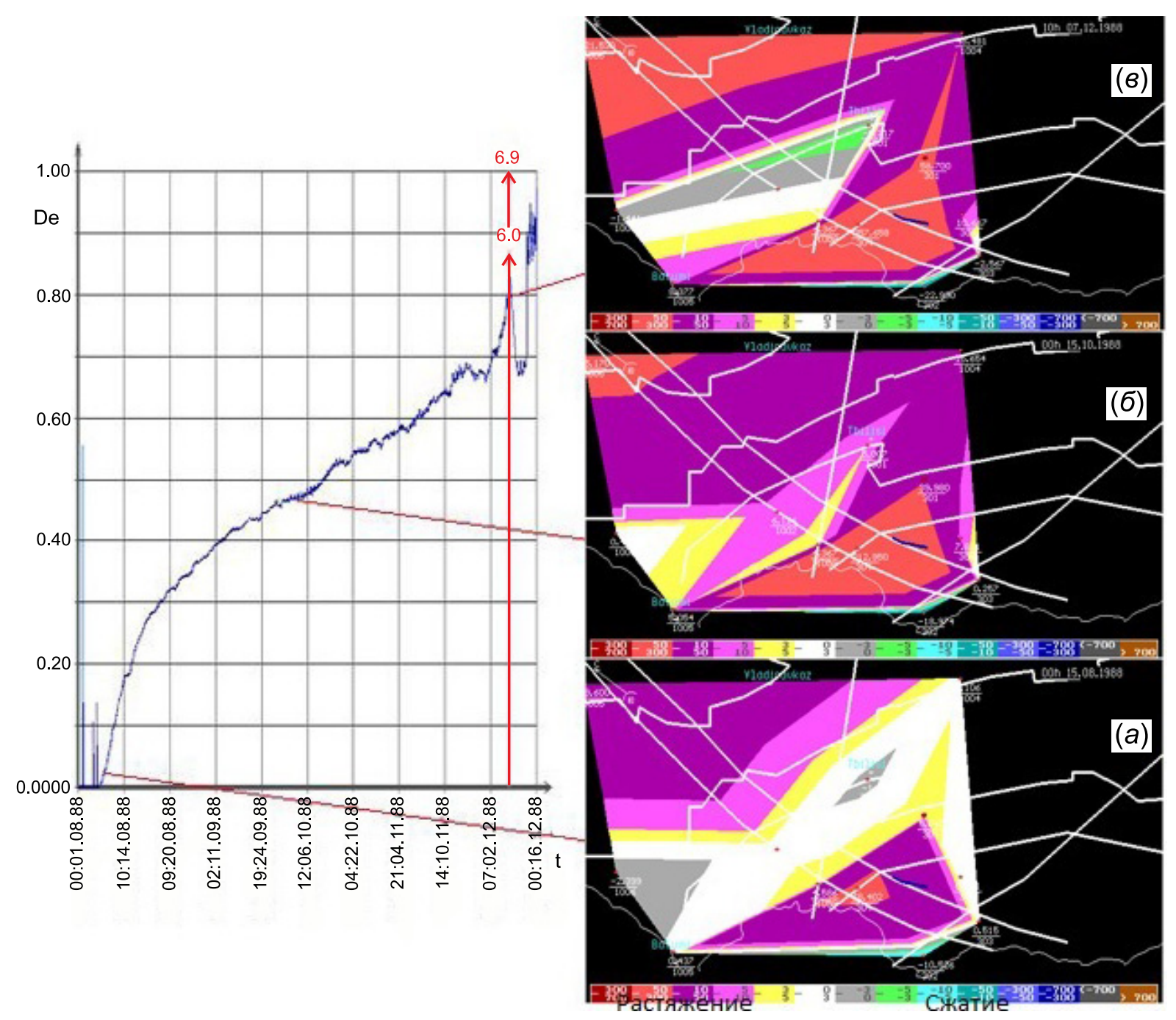

Рис. 1. Кавказский полигон ГГД-мониторинга. Развитие деформационной обстановки в период подготовки 00:00.15.08.1988 г. (a); 00:00.15.10.1988 г. (б) и за сорок одну минуту до главного удара Спитакского землетрясения, 10:00.07.12.1988 г. (в). Красные и фиолетовые поля - структуры растяжения. Серые, зеленые - структуры сжатия. Белые жирные линии - основные системы разломов на Кавказе. Короткая синяя линия - разлом, который образовался в результате землетрясения.

Fig. 1. The Caucasus HGD monitoring polygon. $(a)$ - development of the deformation situation during the preparation period of 00:00.15.08.1988; (б) - 00:00.15.10.1988, and ( 6 ) - 41 minutes before the main shock of the Spitak earthquake, 10:00.07.12.1988. Fields: red, purple - extension structures; gray, green - compression structures. White thick lines - main fault systems of the Caucasus. Short blue line - fault formed as a result of the earthquake.

Исследования особенностей скоротечных деформационных процессов в литосферном пространстве, которые выполнены на основе методологии новой дисциплины - региональной гидрогеодеформатики, показывают, что каждое мощное сейсмическое событие характеризуется своей «индивидуальной» меткой - деформационным импульсом длительностью в несколько месяцев, который дает представление о заключительной фазе подготовки и моменте реализации сейсмического события [Vartanyan, 2006, 2007, 2010, 2015]. Этот импульс по своей физической сущности является отображением двух процессов, протекающих в ли- тосферных образованиях, скоротечного поднятия крупных геологических массивов и связанного с этим разуплотнения материала горных пород, которое сопровождается формированием серии короткоживущих структур растяжения. Ареалы воздымания, где генерируется мощный деформационный импульс растяжения, в зависимости от энергии будущего землетрясения могут охватывать площади в сотни тысяч - несколько миллионов квадратных километров. Полученные в эпицентральной и в близэпицентральной областях метки-импульсы ряда землетрясений отличаются друг от друга длительностью существования, но 
(a)

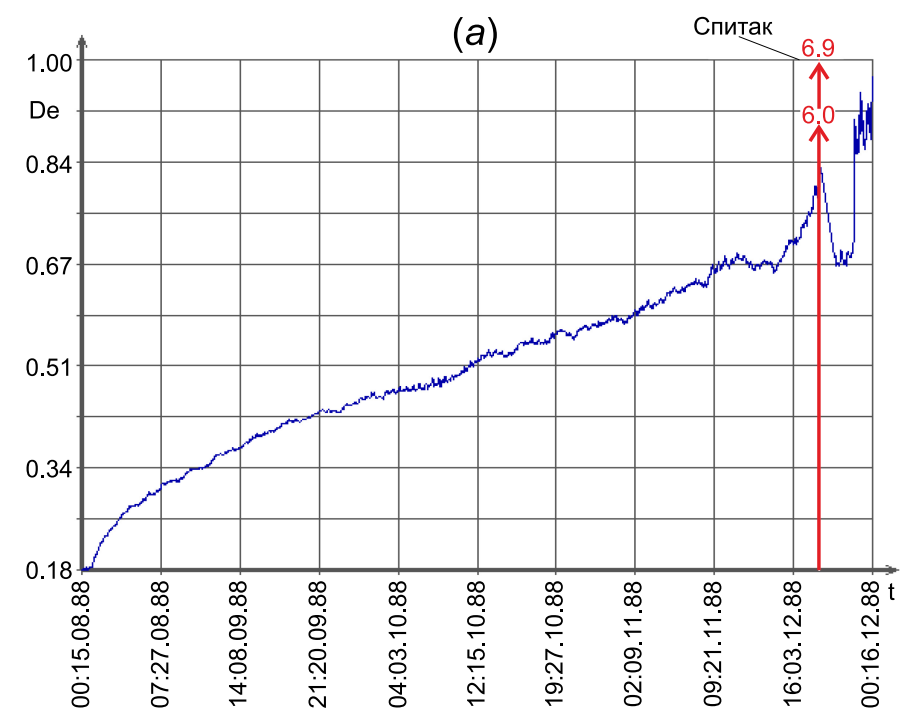

(б)

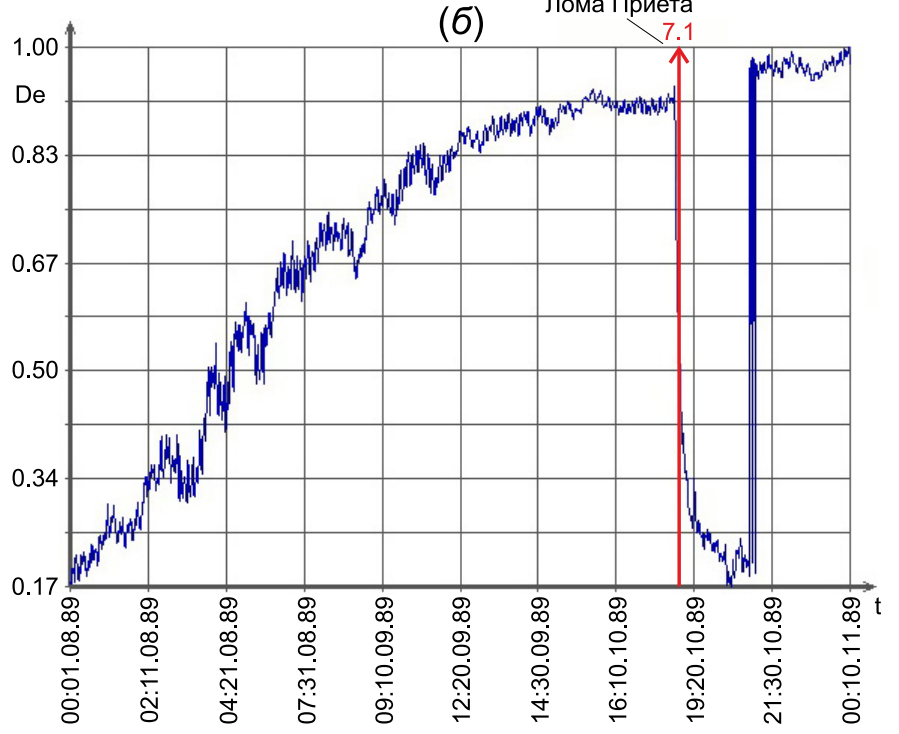

(в) Хоккайдо

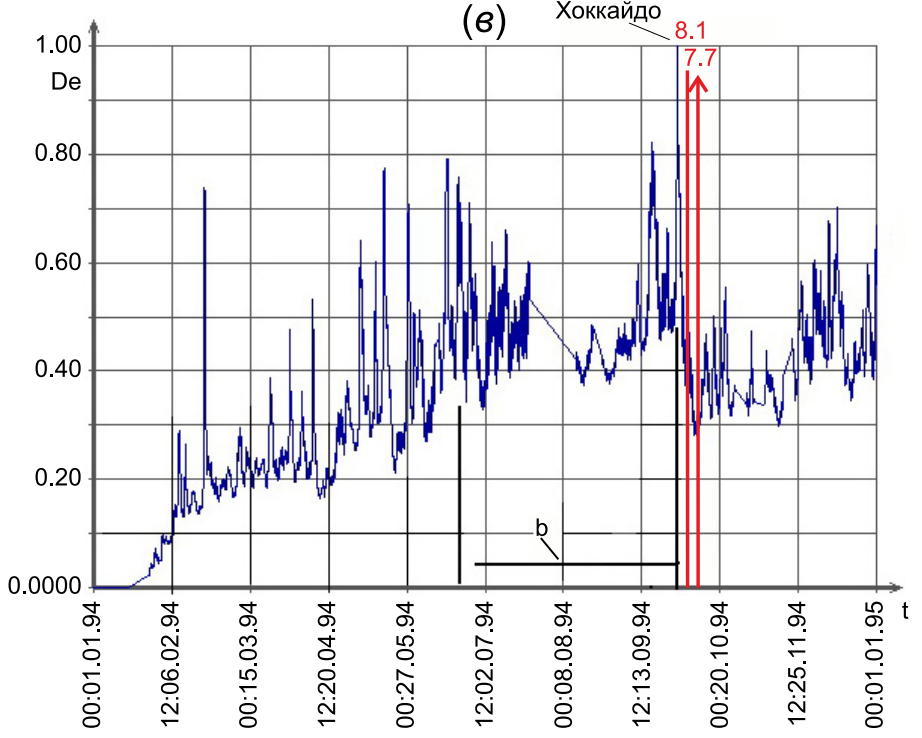

схожи по конусовидному облику деформограмм (рис. 2). Так, начальные, круто восходящие участки графиков характеризуют период высоких темпов роста структур растяжения и отличаются доста-
Рис. 2. Деформограммы заключительного периода подготовки и реализации землетрясений: $(a)$ - Спитак (07.12.1988 г.); (б) - Лома Приета (18.10.1989 г.); (в) Хоккайдо (04.10.1994 г.) по результатам ГГД-мониторинга на полигоне на Кавказе, в Калифорнии (Паркфилд) и на о. Хонсю (полигон Суруга), соответственно. Участок деформограммы, обозначенный литерой «b», - предсейсмическое седлообразное понижение.

Fig. 2. Deformograms of the final period of preparation and occurrence of earthquakes: $(a)$ - Spitak (07.12.1988); (б) - Loma Prieta (18.10.1989); (в) - Hokkaido (04.10. 1994), according to the HGD monitoring of the polygons in the Caucasus, California (Parkfield), and the Honshu Island (Suruga polygon), respectively. A portion of the deformogram marked with letter " $b$ " - pre-seismic saddle-shaped depression. точно «плавными» очертаниями. Продолжительность этой части процесса составляет несколько месяцев. Далее отмечается переход кривой в субгоризонтальную или седловидную часть, что свиде- 
тельствует о приостановке развития короткоживущих структур. Пауза в развитии структур растяжения может быть истолкована и как результат прекращения действия сил, вызывающих деформации, и как противодействие прочностных свойств геологического материала прикладываемым нагрузкам. Как следует из деформограмм ряда землетрясений, такое состояние длится от 12-15 суток до нескольких месяцев и характеризует состояние жестких горных пород, которые достигли предела длительной прочности. Вслед за этим на графике прослеживается небольшой и очень кратковременный скачок разуплотнения, за которым следует крутопадающая часть деформограммы. Она отвечает процессу резко наступивших сжатий, разрушения массива и разрядки сейсмической энергии.

Исследования кинематики деформационного процесса при землетрясениях дают представление о двух векторах воздействия на массив, который готов к разрушению, - вертикальном и горизонтальном, сдвиговом, причем вертикальный вектор удается проследить как специализированными геодезическими наблюдениями, так и с помощью рассмотренных выше деформограмм. Горизонтальный вектор, несущий во многих эпизодах ответственность за разрушение предельно нагруженного массива, не столь очевиден. Его присутствие и роль в конкретном сейсмическом событии регистрируются с помощью специальных методологических приемов региональной гидрогеодеформатики.

Взаимодействие внеземных объектов с планетой оказывает заметное влияние на состояние геологических образований и проявляется в виде приливных процессов в твердой Земле [Molodensky, 1953; Pariysky, 1960; Melchior, 1966; Magnitsky, 1985; Avsyuk, 1996; Avsyuk et al., 2002; и дp.]. Такие вариации поддаются прямым измерениям на высокоточных стационарных деформографах и проявляются в форме закономерных ритмических вариаций объема геологических образований вследствие быстрых изменений силы тяжести. Регистрация внутриземных приливов требует выполнения прецизионных измерений и позволяет фиксировать деформационные изменения непосредственно в точке наблюдения.

Реконструкции таких деформационных процессов на основе методологии региональной гидрогеодеформатики и анализа стрейн-годографа выявили специфическую форму функционирования ГГД-поля крупных ареалов Земли, что графически представляется как серия амплитудно-модулированных ритмических пульсаций. В стрейн-годографе единичные пульсы выстраивают целостную ритмопачку, продолжительность существования которой составляет 15-16 суток. Ее особенностью является постепенный рост амплитуды составляющих ее импульсов с достижением максимальных значений к середине срока существования всей последовательности и затем - вырождением до нулевых величин и т.д. Сопоставление результатов ГГДстрейн-анализа с графиками, которые получены инструментально на специализированных деформографах, продемонстрировало их идентичность [Vartanyan, 2016].

Такое подобие становится еще одним доказательством трехмерной природы короткоживущих структур деформации, которые, зарождаясь под воздействием комплекса эндо- и экзогенных факторов, существуют в пределах обширных литосферных мегаблоков как пульсирующие объемные образования. Результаты мониторинга свидетельствуют о том, что геодинамически спокойный интервал жизни региона (геоблока) представлен последовательной серией ритмопачек, которые характеризуют закономерный пульсационный отклик литосферных образований на внешние космогенные воздействия. Нарушение установившегося ритма деформационной эволюции становится свидетельством активизации глубинных процессов, которые начинают доминировать в регионе на заключительном этапе подготовки геодинамического события. «Подавление» космогенных ритмов оказывается тем сильнее и регистрируется тем раньше, чем ближе исследуемый геологический блок находится к будущему эпицентру [Vartanyan, 2015, 2016].

Такие состояния хорошо иллюстрируют графики ГГД-мониторинга сейсмических катастроф в Спитаке, Лома Приета и др. В случае надлежащей организации наблюдений за ГГД-полем этот признак мог бы стать одним из надежных критериев для выявления ареала будущей катастрофы и краткосрочного прогноза сейсмического события (рис. 3). Трансрегиональные реконструкции состояния ГГД-поля, выполненные для периодов времени, когда происходили мощные землетрясения, выявили несколько специфических черт скоротечных деформационных процессов.

\section{3. ИНТЕГРАЦИЯ ДЕФОРМАЦИОННЫХ ИМПУЛЬСОВ}

Прослежена одна из замечательных особенностей функционирования ГГД-поля: деформационный импульс, зародившийся в регионе будущего сильного землетрясения, получает многократный повтор в виде импульсов-реплик, мигрирующих к востоку от эпицентра этой сейсмической катастрофы.

Как отмечалось выше, инициирующий импульс в зоне будущего землетрясения регистрируется как конусовидная деформограмма растяжения с 

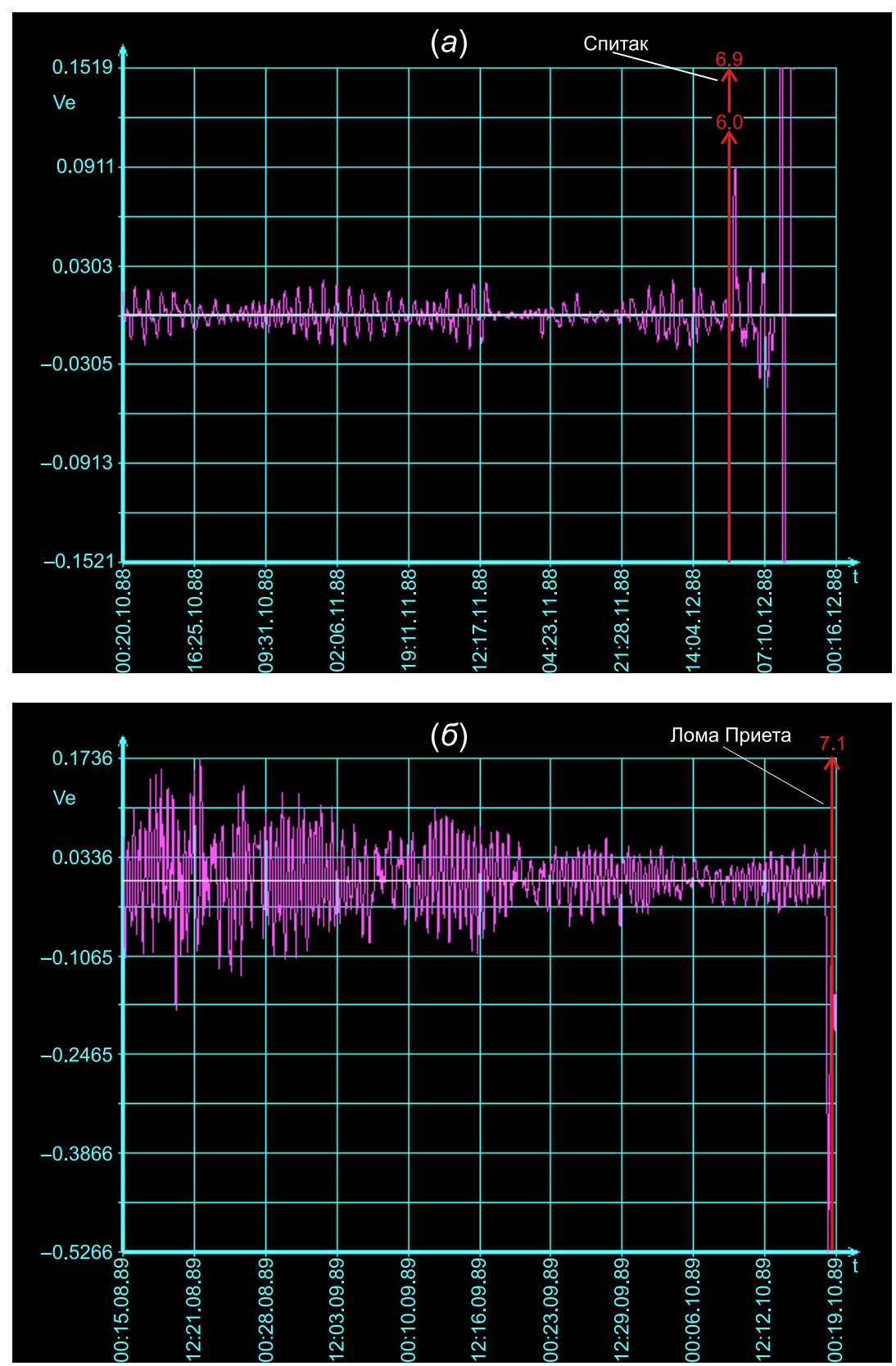

Рис. 3. Годографы (Ve-t, км²/час) периода подготовки землетрясений: Спитак (Кавказ) (a) и Лома Приета (Калифорния) (б).

Fig. 3. Hodographs (Ve-t, $\mathrm{km}^{2} /$ hour) of the earthquake preparation periods: (a) - Spitak (Caucasus); (б) - Loma Prieta (California).

правым, обрывающимся к оси «х» крылом, что свидетельствует о резко возникающих напряжениях сжатия.

С удалением от очаговой зоны на восток интенсивность каждого деформационного сигнала-реплики ослабевает и проявляется со сдвигом во времени по отношению к первичному, тем большим, чем дальше от эпицентра землетрясения находится наблюдаемый регион.

Важные особенности глобального функционирования ГГД-поля выявляются при сопоставлении результатов мониторинга с каталогами сейсмичности.

Как можно заключить по данным мировых сейсмологических служб, сильные землетрясения происходят в короткие интервалы времени своеобразными сериями-квантами и локализуются в пусть очень больших, но в масштабах Земли изолированных ареалах планеты. В данной работе используются сведения о землетрясениях с магнитудой $\mathrm{M=7.0}$ и выше, которые, согласно каталогам USGS, характеризуют поверхностные верти- 
кальные волны (Msz - vertical surface wave magnitude).

Сопоставление такой сейсмологической информации с результатами ГГД-мониторинга дает представление о том, что геологические массивы интегрируют поступающие к ним отдельные деформационные импульсы и формируют единый сигнал. Этот суммарный сигнал от нескольких землетрясений графически представлен кривой, сильно отличающейся от формы импульса одиночного сейсмического события, и характеризует эволюцию деформированного состояния среды конкретного региона после излучения энергии серии сильных землетрясений. Такая суммарная деформограмма становится материализованным образом «генетического сродства» группы сейсмических событий, которые являются следствием специфических циклов скоротечной геодинамической активизации (СГеДА) крупных регионов Земли [Vartanyan, $2014,2015,2016]$. Скорости перемещения такого интегрального деформационного импульса в пространстве оцениваются по временному лагу между пиками на сравниваемых деформограммах и в начале пути не превышают 100-120 км/час, уменьшаясь по мере удаления от очаговой зоны [Vartanyan et al., 2013; Vartanyan, 2015, 2016] (рис. 4).

Обращает на себя внимание частичное взаимное «перекрытие» таких интегральных сигналов-реплик, которые регистрируются в сопоставляемых и удаленных друг от друга регионах. С одной стороны, это свидетельствует о зарождении каждого из таких сигналов in situ, а с другой - указывает на существование каких-то механизмов, которые обеспечивают связь сигналов-реплик с первичным деформационным импульсом в очаге землетрясения.

Типичными, например, являются совмещенные деформограммы по регионам «Хонсю - ТяньШань», «Кавказ - Калифорния», «Кавказ - Дальний Восток - Канадские Кордильеры», дающие представление о сопряженности во времени процессов, которые являются реакцией среды на подготовку той или другой серии сейсмических событий (рис. 4).

Подготовка и разрядка землетрясения Маккуари (Тасманово море, 23.05.1989 г., M=8.2) проявились на деформограммах Малого Кавказа (блок 11, скв. 0301, 0308, 1001) и Калифорнии (Паркфилд) в виде резких обрывов на кривой, что характеризовало сильные сжатия 01.06.1989 г. - на Кавказе и 10.06.1989 г. - в Калифорнии.

«Сопряженное» развитие деформационной обстановки как результат подготовки и разрядки сильного землетрясения на о. Хоккайдо (04.10.1994 г., $\mathrm{M=8.2)}$ прослежено по исходным данным с полигона Суруга (наблюдения за уровнями воды в скважинах, GSJ) и результатам ГГД-мониторинга в предгорьях Тянь-Шаня.

Три совмещенные деформограммы по Кавказу, российскому Дальнему Востоку и Канадским Кордильерам дают четкую картину увязки процессов, которые происходили при «созревании» и реализации серии сильных землетрясений в Чили (Mayле, 27.02.2010 г., M=8.8, и другие) и в Японии (Тохоку, 11.03.2011 г., М=9.0).

С учетом существующих представлений о геолого-тектоническом устройстве земной коры установленный феномен быстрой субглобальной или даже глобальной «миграции» деформационного импульса труднообъясним. По трассе возникновения таких специфичных видов объемного геофизического сигнала находятся множественные генетически различные и разновозрастные геологические образования с сильно отличающимися друг от друга свойствами проводимости, пьезопроводности, способностями реагировать на деформационные нагрузки и др. Иными словами, пройдя через геологические структуры, такое «неударное» возмущение должно было бы сравнительно быстро затухать [Shchelkachev, 1946; Polubarinova-Kochina, 1952; Bredehoeft, 1967; Hsieh et al., 1988; Rice, Cleary, 1976; Rice, Rudnicky, 1979; Rice, 1992]. В полученной серии наблюдений затухание не регистрируется и, наоборот, в отдельных случаях отмечается рост контрастности деформационного импульса как результат сложения исходных импульсов от серии землетрясений. Отсюда следует, что собственно земная кора в качестве глобального проводника выявленных деформационных сигналов рассматриваться не может.

\section{4. ФЛЮИДОСФЕРА И ГЭДС КАК СРЕДА ПОДГОТОВКИ ГЕОДИНАМИЧЕСКИХ КАТАСТРОФ}

Если многие проявления ГГД-поля могли быть истолкованы с позиций подземной гидравлики и гидродинамики, то большая группа деформационных процессов, включая такие, как возникновение предсейсмического деформационного импульса, его глобальная миграция в виде сигналов-реплик, природа скоротечных деформационных циклов и др., нуждались в поиске механизмов, которые ответственны за эти и другие явления в литосферном пространстве.

Кроме того, критический анализ обширного материала ГГД-реконструкций становится особенно актуальным, поскольку эти результаты давали основание утверждать: сильным землетрясениям предшествует достаточно длительный период отчетливо выраженных процессов растяжения в эпицентральных и близрасположенных зонах. И 

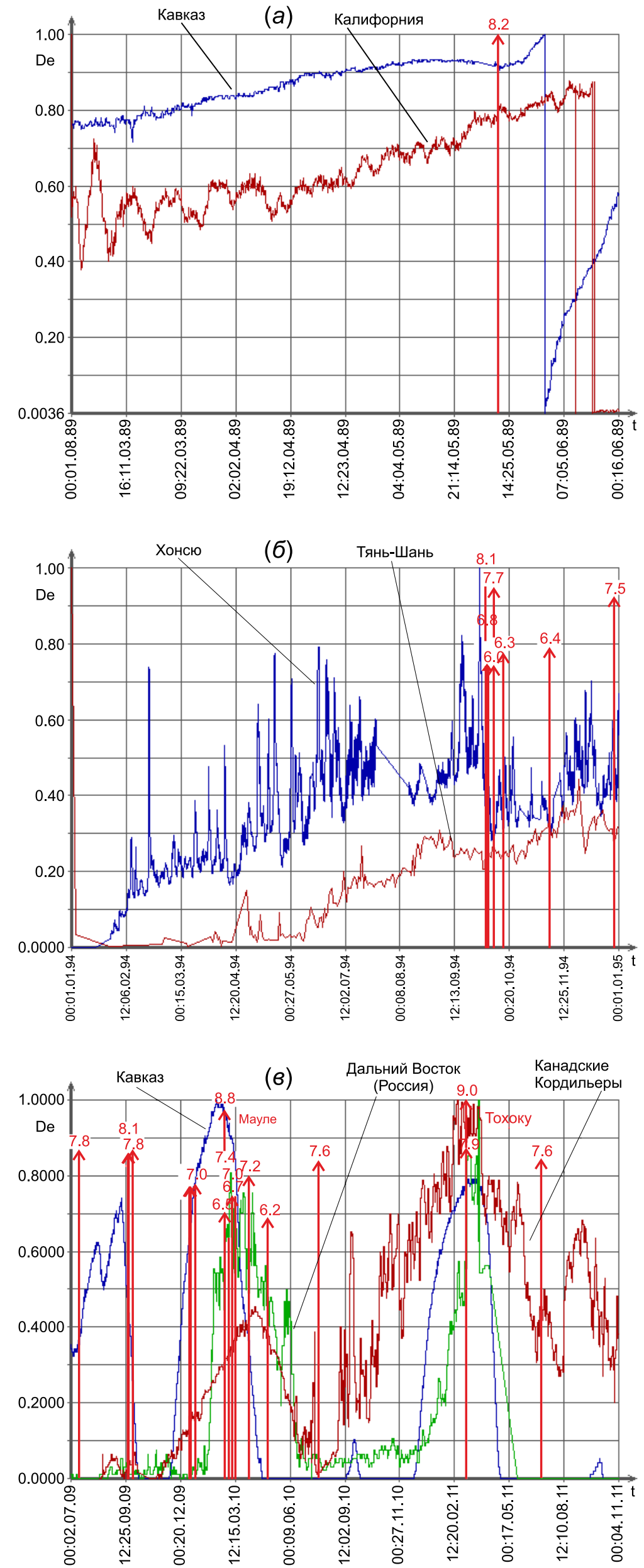

Рис. 4. Совмещенные деформограммы: $(a)$ - Кавказ (блок 11, Ноемберян - Севан - Лагодехи) и Калифорния (Паркфилд) - реакция на землетрясение Маккуари (M=8.2, 23.05.1989 г.); (б) - о. Хонсю и Тянь-Шань - реакция на землетрясение на о. Хоккайдо (М=8.3, 04.10.1984 г.); (в) - Большой Кавказ, российский Дальний Восток, Канадские Кордильеры - реакция на землетрясения Мауле $(\mathrm{M}=8.8$, 27.02.2010 г., Чили) и Тохоку (M=9.0, 11.03.2011 г., Япония). Красные вертикальные линии - сильные землетрясения (M=7.0 и выше).

Fig. 4. Combined deformograms: (a) - Caucasus (Block 11, Noemberyan - Sevan - Lagodekhi) and California (Parkfield) - reaction to the M 8.2 23.05.1989 Macquarie earthquake; (б) - Honshu Island and Tien Shan - reaction to the M 8.3 04.10.1984 Hokkaido earthquake; ( 8 ) - Greater Caucasus, Russian Far East, Canadian Cordillera - reaction to the M 8.8 27.02.2010 Maule earthquake (Chile) and M 9.0 11.03.2011 Toho$\mathrm{ku}$ earthquake (Japan). Red vertical lines - strong earthquakes $(M \geq 7.0)$. 
только очень краткие моменты, связанные с разрушением массива и излучением упругой энергии, приходятся на сжатие толщ. Таким образом, результаты исследований ГГД-поля Земли вступали в известное противоречие с господствующей концепцией, согласно которой мощным сейсмическим проявлениям предшествуют коллизионные процессы в межплитных пространствах.

Такое положение вещей обусловило необходимость поиска некоторой целостной модели деформируемого пространства, которая позволила бы дать непротиворечивое истолкование результатов большого объема исследований ГГД-поля Земли в сочетании с информацией о мировой сейсмичности. Иными словами, обнаружение ряда новых гидродинамических явлений в геологическом пространстве послужило предпосылкой для разработки представлений о специфическом планетарном образовании - флюидосфере Земли и планетарной мегаструктуре - ГЭДС [Vartanyan, 1977, 1993, 2000, 2006, 2008a, 2013, 2015, 2016].

Помимо общегеологических соображений и рассмотренных результатов ГГД-мониторинга, в пользу такой модели свидетельствовало большое количество геофизических и термодинамических исследований, показавших, что на глубинах 2900, 410-660 и 100-300 км ниже поверхности Земли существуют резервуары, накапливающие огромные объемы расплавов глубинного вещества [Dobretsov, Kirdyashkin, 1994; Kalinin et al., 1989; Kopnichev, Sokolova, 2003; Krasnyi, 2000; Letnikov, Dorogokupets, 2001; Letnikov, 2002; Marakushev, 2002; Zhao et al., 1996; Wolfe et al., 1997, 2009; Fyfe et al., 1978; van der Hilst et al., 1997; Hofmann, 1997; Lithgow-Bertelloni, Silver, 1998; Borell, 2009; и дp.].

В рассматриваемой модели флюидосферы и глобальной эндодренажной системы учитывается интенсивный разогрев глубинных частей планеты как главный фактор генерации огромных объемов миграционно активных масс расплавов и «легких» флюидов (как ювенильных, так и метаморфогенных) [Vartanyan, 1968, 1977, 2000, 2004, 2010, 2015, 2016]. Для последующих оценок в качестве отправной позиции было принято, что процессы выплавки, ликвационного разделения высоконапорных продуктов по плотностям, транспорта и «переотложения» их наиболее легких фракций во внешних частях разреза возникли на самых ранних стадиях геологической жизни Земли.

Вынос к поверхности исполинских объемов флюидного вещества обеспечивал становление геологической оболочки Земли и одновременно с этим формировал «дефект массы» на глубинах, откуда эвакуировался расплавленный материал. Одним из следствий течения таких процессов стало заложение и развитие обширных впадин проседа- ния, которые покрывали поверхность Земли [Markhinin, 1967; Milanovsky, 1968; Avdalovich, 1972, 1973; u $\partial p$.]. Параллельно с масштабными излияниями тяжелых расплавов на поверхность, вода - важный и, вероятно, наиболее объемный продукт плавки глубинного вещества - заполняла образующиеся впадины и формировала океаны. Восприняв температуру внешней среды, океаническая вода, как высокоинерционный тепловой флюид, оказалась тем природным фактором, который в ареале своего скопления стал воздействовать на геотемпературную обстановку геологического пространства ниже дна океанов.

Одним из следствий существования этого теплового экрана должно было стать значительное по масштабам перераспределение разгрузки тепла и восходящих флюидов от центральных, наиболее глубоко охлаждаемых, частей океанических впадин в сторону их периферии. Как результат, происходило сокращение расхода глубинных флюидов через океаническое дно и возрастали доли потоков на внешних границах океанов. И хотя океанические впадины сохранили за собой значительную долю разгрузки глубинных флюидов, часть этих продуктов, оказывая определяющее воздействие на геодинамическую жизнь Земли, стала поступать к дневной поверхности по формирующейся ГЭДС. Эта планетарная мегаструктура представлена серией уходящих глубоко в недра планеты «каналов», которые на уровне астеносферного слоя флюидофизически (гидравлически) тесно взаимосвязаны.

В современном виде морфологически ГЭДС проявлена на поверхности как линейно вытянутая и глобально разветвленная совокупность материковых горно-складчатых сооружений, рифтов, срединно-океанических хребтов, поднятий и кряжей, интенсивно растущих островных дуг. Важной чертой собственно коровой части этой глобальной мегаструктуры является ее высокая степень делимости на множественные мега-, мезо- и микроблоки, каждый из которых, отвечая генеральному тренду текущей деформационной эволюции региона, отличается особенностями индивидуальной реакции на развивающиеся геодинамические процессы. В пределах ГЭДС реализуется концентрация тепла, жидких и летучих продуктов глубокой трансформации вещества и происходит их перенос к поверхности. Функционирование такой специфической системы обеспечивается ее открытостью во внешнее пространство и прямой связью с гидро- и атмосферой Земли. Взамен выносимых продуктов, для компенсации дефекта массы, который мог бы образоваться на глубине, по нисходящей ветви мегаструктуры погружаются геологические образования в весовом соотношении, равном «потерянной» доле расплавов и газов. Этими процессами реали- 
зуется одна из важнейших функций ГЭДС - сброс критических нагрузок на жесткие геологические образования через многочисленные формы геодинамической активности и, одновременно, выравнивание «потери» вещества в глубинных зонах.

В пределах рассматриваемых гигантских тепломассообменных петель, связывающих земную кору и астеносферу, в реальном времени происходят контрастные вариации практически всех составляющих геофизического поля Земли, включая ее сейсмичность. Кроме того, перераспределяя в пространстве флюидные продукты и напряжения, ГЭДС, по существу, выполняет функции основного «движителя» для горизонтальных перемещений протяженных блоков литосферы.

В процессах увеличения объема Земли [Carey, 1988; Milanovsky, 1978, 1995; и дp.] глобальная эндодренажная система является пульсационно развивающейся растущей мегаструктурой [Vartanyan, 2000, 2003, 2006, 2008a, 2010, 2013, 2015, 2016]. C учетом таких представлений рассмотрим некоторые особенности функционирования астеносферы как важнейшей связующей основы между ГЭДС и верхней мантией, которая флюидофизически управляет развитием геодинамических процессов во всей эндодренажной системе Земли.

Существующие на сегодняшний день представления об астеносфере базируются на результатах дистанционных геофизических исследований и теоретических построений, что во многом предопределяет существование в научной литературе неоднозначных, иногда противоречащих друг другу суждений [Pavlenkova, 2001, 2004; Khain, Lomize, 2005; Kirdyashkin et al., 2005; Lambeck, Johnson, 1998; Prouteau at al., 2001; Stacey, Davis, 2008; Liu, Liang, 2017; и дp.]. Вместе с тем оценки астеносферы как пограничного слоя между верхней мантией и земной корой общеприняты. Далее рассмотрим возможные процессы, которые обеспечивают формирование глобальной эндодренажной системы.

В догеологическую эпоху мантийное вещество имело непосредственный контакт с внешним пространством, а температура излияния расплавов на поверхность могла отвечать температурам базальтовых лав (1100-1400 $\left.{ }^{\circ} \mathrm{C}\right)$, которые установлены современными прямыми измерениями при извержениях в вулканических областях. С возникновением геологической оболочки, увеличением ее мощности и становлением обширных, перекрывающих планету флюидоупоров-тепловых экранов условия «свободного истечения» глубинного расплава и газов во внешнее пространство существенно менялись. Так, растущие мощности геологических образований и увеличение литостатического давления на кровлю верхней мантии должны были оказывать «угнетающее» воздействие на процессы «выхода» глубинного вещества в близповерхностные части планеты. С ростом литостатических давлений одновременно должны были возрастать температуры, которые могли требоваться для перехода твердого, но пластичного пиролита (?) в другие фазовые состояния.

На таком общепланетарном фоне складывались очень специфические условия для миграции и перераспределения мантийного вещества в пространстве. При этом одним из ведущих факторов, оказывающих влияние на локализацию разгрузки глубинного материала в близповерхностные части планеты, стали неровности в поверхности мантии, которые обусловили ареальную неравномерность поля литостатических давлений и температур. Меняющиеся в пространстве термобарические условия предопределили возникновение ареалов с аномально низкими давлениями, которые совпадали с наиболее приподнятыми участками мантии. Можно полагать, что именно с такими участками сопрягаются очаги геологически длительно функционирующей эндодренажной системы Земли.

Возможные пути и механизмы миграции мантийного материала в дренажной системе и формы реализации таких процессов разгрузки заслуживают особого обсуждения. Наблюдая сооружения ГЭДС вдоль их простирания, можно говорить о серии тесно взаимоувязанных мегаблоков, выстраивающих «целостные» морфологические образования с близкими режимами геодинамической жизни. В частности, для одного из элементов ГЭДС - отдельных горно-складчатых сооружений - характерны «равные» темпы вертикального роста больших групп мегаблоков, схожие геотемпературные режимы, однородная геохимическая специализация эманирующих газовых флюидов и, по-видимому, близкие глубины залегания астеносферного слоя.

Для поперечного сечения глобальной эндодренажной системы характерны значительные перепады в высотных положениях кровли верхней мантии (по существу, кровли астеносферы) - от первых километров под океанами до 80-100 км и глубже под материками, причем под горно-складчатыми сооружениями исследователи отмечают существование глубоких «корней», что обычно объясняется избыточной нагрузкой тяжелых коровых блоков, которая «погружает» их в астеносферный слой. Вместе с тем, рассматривая комплекс таких факторов, как существование значительных градиентов литостатических давлений и геотемператур, направленных от наиболее глубоко погруженных частей верхней мантии к так называемым «корневым» частям горно-складчатых сооружений, можно сделать заключение о том, что существует постоянно действующий очень медленный, но геологически значимый субгоризонтальный «поток» пла- 
стичного пиролита, который вызывает развитие широкой гаммы процессов на границе между мантией и земной корой и опосредованно, в собственно геологической оболочке Земли. Одним из важнейших результатов такого течения является возникновение и геологически длительное функционирование астеносферного слоя как следствие дифференциации материала пиролита: глубинное вещество, которое выжимается из зон наиболее высоких литостатических давлений и латерально двигается вверх вдоль кровли мантии, после пересечения некоторой плоскости с критическим давлением (Р (расплав) и газовую компоненту в объемах, отвечающих давлениям, встречающимся на пути своего движения. По мере медленного перемещения глубинного вещества вдоль кровли верхней мантии интенсивность дифференциации материала по плотностям нарастает, а результирующая такого движения приводит к постепенному увеличению мощности астеносферы, отличающейся низкой плотностью по сравнению и с верхней мантией, и с отделяемыми от мантии геологическими образованиями. Мощности астеносферного слоя, вероятно, нарастают по направлению к основаниям горно-складчатых сооружений. Увеличение мощности астеносферного слоя может происходить за счет ранее образовавшихся, «подстилающих» флюидных масс, то есть прирост толщины слоя происходит снизу вверх.

В результате таких процессов в основании ГЭДС, непосредственно под горно-складчатыми сооружениями, образуются специфические куполоподобные термобарические аномалии, которые оказывают динамическое (пневмогидродинамическое) воздействие на вышележащие литосферные мегаблоки, приподнимая и меняя их высотное положение. В некоторых предельных состояниях такие процессы должны приводить к разрушению нагруженных жестких образований корового пространства. С таких позиций, вероятно, можно объяснять существование временных интервалов между сильными сейсмическими событиями, которые эмпирическим путем отмечены для некоторых конкретных сейсмически активных регионов мира. В таких случаях после «сброса» критических напряжений, который следует за землетрясением, непосредственно под конкретным сейсмическим регионом начинается новый цикл накопления флюидов (упругой энергии) в астеносферном пространстве, вплоть до достижения нового «предела» и т.д.

Иными словами, в общем случае накапливаемые длительное время в астеносфере пневмофлюидные аномалии становятся фактором прямого воздействия на геомеханическое состояние вышерасположенного корового пространства.
Если положение подошвы астеносферного слоя в пространстве определяется кривизной поверхности верхней мантии, то формирование его верхнего ограничения протекает при активном термохимическом воздействии перегретых глубинных флюидов (прежде всего, их газовой составляющей) на «холодные» породы в подошве коры. Для сохранения устойчивости пространственного положения кровли астеносферного слоя в такой термобарически неравновесной системе должны соблюдаться условия, отвечающие зависимости:

$$
\Delta \mathrm{P}=0 \text { и } \Delta \mathrm{P}=P_{\mathrm{fl}}-\left(P_{\mathrm{lts}}+P_{\mathrm{hyd}}+P_{\mathrm{atm}}+\ldots\right),
$$

где $P_{\mathrm{fl}}$ - давление глубинного флюида на кровле астеносферы; $P_{\text {lts }}=\mathrm{P}_{\text {lts }} \pm \Delta \mathrm{P}_{\text {lts }}$ - литостатическое давление на подошве коры и возможные вариации; $P_{\text {hyd }}=\mathrm{P}_{\text {hyd }} \pm \Delta \mathrm{P}_{\text {hyd }}$ - гидростатическое давление (вод суши, подземной гидросферы и Мирового океана) и возможные вариации; $P_{\mathrm{atm}}=\mathrm{P}_{\mathrm{atm}} \pm \Delta \mathrm{P}_{\mathrm{atm}}$ - атмосферное давление и отклонения от нормы.

Из отмеченного следует, что астеносфера является упругим несущим основанием для вышележащих геосфер Земли, предопределяющим возможности развития сложных геомеханических процессов в жестких геологических толщах. Одновременно эта заполненная высоконапорным надкритическим флюидом объемная мембрана сама очень чувствительна к внешним и глубинным (внутримантийным) термобарическим возмущениям.

Именно высокая чувствительность астеносферы делает ее местом, где совокупное воздействие внешних и глубинных факторов на текущее состояние матрицы (например, изменение баланса давлений, рост или падение температуры флюида) способно менять несущие свойства среды и создавать предпосылки для развития опасных геодинамических процессов в вышележащей геологической части разреза. Изменение одного из параметров, входящих в зависимость (1), должно приводить к соответствующей смене положения кровли астеносферы и через это влиять на напряженнодеформированное состояние всей вышележащей толщи. Так, например, рассмотренные ранее амплитудно-модулированные деформационные пульсации в геологическом пространстве, безусловно, следует признать откликом флюидсодержащего астеносферного слоя на воздействие одного из важнейших внешних факторов - космогенных вариаций силы тяжести.

\section{5. НЕКОТОРЫЕ ВОЗМОЖНЫЕ МЕХАНИЗМЫ ГЕНЕРАЦИИ АСТЕНОСФЕРНОГО СЛОЯ И ИХ СЛЕДСТВИЯ}

В рассматриваемых процессах на долевое соотношение жидких, вязких и газообразных продук- 


\section{Соотношения масс минералов, участвующих в метаморфических реакциях}

Mass ratios of minerals involved in metamorphic reactions

\begin{tabular}{|c|c|c|c|}
\hline \multirow[t]{2}{*}{$\begin{array}{l}\text { Метаморфическая } \\
\text { фация }\end{array}$} & \multicolumn{2}{|c|}{$\begin{array}{l}\text { Масса реагирующих минералов и газовожидких продуктов реакции } \\
\text { (усл. весов. единицы) }\end{array}$} & \multirow[t]{2}{*}{$\begin{array}{l}\% \% \text { от массы реагирую- } \\
\text { щих минералов }\end{array}$} \\
\hline & Минералы левой части уравнения & Сумма газовых, жидких продуктов & \\
\hline Зеленые сланцы & $\begin{array}{l}6 \text { кальцит + } 5 \text { тальк + } 4 \text { кремнезем } \\
(2730 \text { кг) }\end{array}$ & $\begin{array}{l}2 \mathrm{H}_{2} \mathrm{O}+6 \mathrm{CO}_{2} \\
(300 \text { кг) }\end{array}$ & 10.99 \\
\hline Зеленые сланцы & $\begin{array}{l}3 \text { мусковит + } 6 \text { кремнезем + } 4 \text { кальцит } \\
\text { (1954 кг) }\end{array}$ & $\begin{array}{l}2 \mathrm{H}_{2} \mathrm{O}+4 \mathrm{CO}_{2} \\
(212 \mathrm{\kappa})\end{array}$ & 10.85 \\
\hline Зеленые сланцы & $\begin{array}{l}10 \text { кальцит +21 кремнезем + } 3 \text { хлорит } \\
\text { (3922 кг) }\end{array}$ & $\begin{array}{l}8 \mathrm{H}_{2} \mathrm{O}+10 \mathrm{CO}_{2} \\
(584 \text { кг) }\end{array}$ & 14.86 \\
\hline Зеленые сланцы & $\begin{array}{l}4 \text { лавсонит + } 2 \text { кварц } \\
(1376 \text { кг) }\end{array}$ & $\begin{array}{l}6 \mathrm{H}_{2} \mathrm{O} \\
(108 \text { кг) }\end{array}$ & 7.85 \\
\hline Гранулит & $\begin{array}{l}6 \text { кварц + } 3 \text { кальцит + флогопит } \\
\text { (1076 кг) }\end{array}$ & $\begin{array}{l}3 \mathrm{CO}_{2} \\
(132 \text { кг })\end{array}$ & 12.26 \\
\hline Гранулит & $\begin{array}{l}\text { анортит + } 2 \text { кальцит + кварц } \\
\text { (538 кг) }\end{array}$ & $\begin{array}{l}2 \mathrm{CO}_{2} \\
(88 \text { кг })\end{array}$ & 16.38 \\
\hline Гранулит & $\begin{array}{l}\text { биотит + мусковит + } 3 \text { кварц } \\
(1090 \text { кг) }\end{array}$ & $\begin{array}{l}\mathrm{H}_{2} \mathrm{O} \\
(18 \text { кг) }\end{array}$ & 1.65 \\
\hline Гранулит & $\begin{array}{l}\text { флогопит + флогопит + } 3 \text { кварц } \\
\text { (994 кг) }\end{array}$ & $\begin{array}{l}2 \mathrm{H}_{2} \mathrm{O} \\
(36 \text { кг) }\end{array}$ & 3.62 \\
\hline Гранулит & $\begin{array}{l}3 \text { кварц + биотит } \\
\text { (596 кг) }\end{array}$ & $\begin{array}{l}\mathrm{H}_{2} \mathrm{O} \\
(18 \text { кг) }\end{array}$ & 3.02 \\
\hline Гранулит & $\begin{array}{l}3 \text { кальцит + роговая обманка + } 2 \text { кварц } \\
(150 \text { кг) }\end{array}$ & $\begin{array}{l}3 \mathrm{CO}_{2}+\mathrm{H}_{2} \mathrm{O} \\
(150 \mathrm{\kappa})\end{array}$ & 12.2 \\
\hline
\end{tabular}

тов вдоль протяженности астеносферы может влиять как вещественный состав материала, который, вероятно, неоднороден на разных участках поверхности верхней мантии, так и уровень ее нагретости.

Оценивать реальные объемы вещества, медленно поступающие в астеносферу со всей поверхности верхней мантии, так же, как и судить о долевом соотношении жидкой и газообразной составляющих такого флюида, не представляется возможным, однако, с учетом имеющихся наблюдений за вулканическими извержениями, утверждения о первых процентах содержания собственно «жидкости» (расплава) в пограничном слое между корой и мантией можно принимать как вполне реалистичные. Эти расплавы являются средой, гидравлически связывающей все элементы ГЭДС.

Остальная, бо́льшая, доля флюида в астеносфере, видимо, приходится на высоконапорную газовую составляющую, которая распределяется в массе вязкого материала и занимает преимущественно высокие этажи разреза астеносферы. Для представлений о возможных следствиях выделения летучих из мантийного материала, по-видимому, могла бы оказаться полезной отдаленная аналогия с реакциями регионального метаморфизма, когда при высоких температурах образуются новые, более плотные минеральные соединения и генерируется газовая составляющая.
Так, например, в результате высокотемпературных превращений в комплексе гранулитовой фации анортит - кальцит - кварц образуются водяные пары и углекислый газ в количестве 16.38 весовых процентов от исходной массы или при весе реагирующих минералов в 538 кг вырабатывается 88 кг воды и $\mathrm{CO}_{2}$. Метаморфическая реакция фации зеленых сланцев: кальцит - тальк - кременезем (2730 кг) дает 10.99 весовых процента летучих, или 300 кг водно-газовых составляющих; реакция кварц - кальцит - флогопит (1076 кг) дает 12.26 весовых процентов флюидов от начальной массы реагирующих компонентов, или 132 кг воды и $\mathrm{CO}_{2}$ и др. (таблица).

Вместе с тем все изначально глубинные образования, которые участвуют в построении земной коры, на протяжении своей геологической жизни многократно подвергались процессам «высушивания» и по сравнению с исходным мантийным веществом, по-видимому, истощены летучими компонентами. Обоснованно можно полагать, что выход газово-жидкой составляющей при флюидизации пиролита в весовом и, тем более, в объемном отношении должен оказаться существенно выше тех величин, которые приведены в таблице.

Рассматриваемая модель дает основание предполагать, что поступление мантийного материала, «подпитывающего» ГЭДС и обеспечивающего рост 
(a)

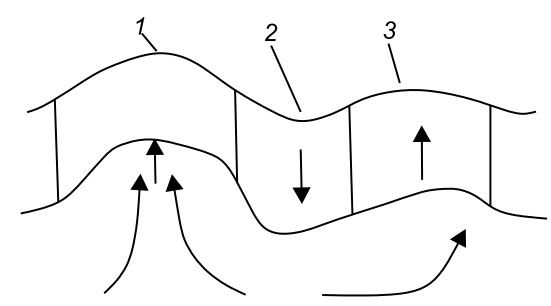

(б)

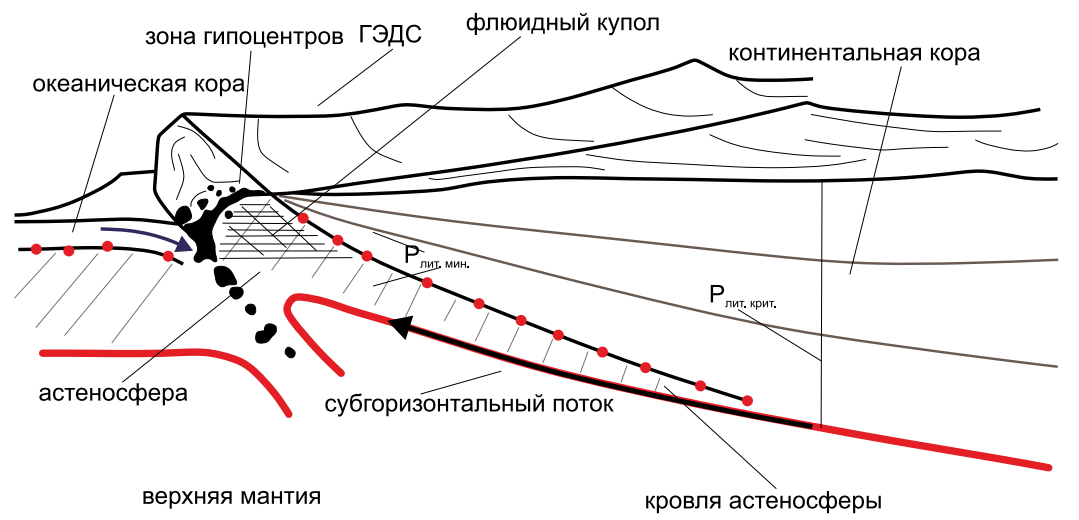

Рис. 5. Схематические профили через эндодренажную систему: (a) - вдоль, (б) - вкрест простирания.

Fig. 5. Schematic profiles across the endodrainage system: (a) - along the strike; (б) - across the strike. горно-складчатых сооружений, геологически длительное время осуществляется со стороны флангов этой планетарной мегаструктуры (рис. 5). В такой интерпретации ГЭДС представляет собой комбинированную мантийно-коровую глобальную мегаструктуру, определяющую современный режим геодинамической жизни Земли и всех сопутствующих этому проявлений, включая сейсмичность.

Одним из важных свидетельств в пользу такой модели являются результаты большого цикла исследований геологических образований в Скалистых горах Канады, а также в сопредельных частях Западно-Канадского щита [Zoback, Zoback, 1980; Gough, Bell, 1981; Cox, 1983; Bell, Babcock, 1986; Bell, McCallum, 1990; Yassir, Bell, 1994]. Этими работами было показано, что, если для горно-складчатых сооружений, участвующих в построении ГЭДС, характерно генеральное состояние растянутости, то на глубинах в пределах смежных структур доминируют напряжения сжатия, то есть те части разреза, которые обычно трактуются как «корни» горноскладчатых сооружений, вдавливаемых в астеносферный слой за счет их большого избыточного веса, по-видимому, не являются таковыми. Здесь крупные коровые элементы, представленные сооружениями ГЭДС, оказываются «взвешенным» раздутием подстилающего астеносферного слоя.

\section{6. ДЕФОРМАЦИОННЫЕ ПРОЦЕССЫ В ЗЕМНОЙ КОРЕ И НЕКОТОРЫЕ ГЕОМЕХАНИЧЕСКИЕ СЛЕДСТВИЯ}

С учетом рассмотренной модели, а также, исходя из высокой делимости геологических образований
ГЭДС на блоки, можно полагать, что упомянутые и, вероятно, другие эволюции неизбежно должны вызывать интенсивные межблоковые горизонтальные напряжения [Vartanyan, 2006]. Как следствие, любые нарушения в установившемся балансе напряжений должны вызывать реакцию каждого из участников такого литосферного ансамбля, направленную на «минимизацию» возникающих несогласий. Вместе с тем процесс «выравнивания» горизонтальных напряжений идет постоянно, никогда не приводя к равновесным состояниям в пространных геологических объектах, о чем свидетельствуют результаты наблюдений за быстро меняющимся состоянием ГГД-поля Земли.

Предсейсмическая эволюция регионального ГгД-поля проходит несколько последовательных фаз - от возникновения обширных, но медленно воздымающихся площадей ГЭДС до сужения ареалов, в которых отмечаются повышенные темпы вертикального роста. Такая локализация, «обозначающая» ареал будущей сейсмической катастрофы, на соответствующих деформограммах фиксируется как импульс растяжений и прослеживается за несколько месяцев до сейсмического события, как показано на рис. 2.

Каждый эпизод поступления напорного флюида из верхней мантии создает в астеносфере обширные по ареальному охвату аномалии давления. Например, если судить по приповерхностным площадям, которые перед рядом сильных землетрясений испытывали воздымание (Рудбар-Манджил, 1990 г., Хоккайдо, 1994 г., и др.), то такие ареалы составляют не менее 10 млн км ${ }^{2}$. Таким образом, можно полагать, что в астеносферном слое ареалы 
«растекания» глубинного флюида могут охватывать площади, во много раз превосходящие те, которые складываются в приповерхностных частях. Вытесняя группу мегаблоков ГЭДС вверх, глубинный флюид обеспечивает доминирование воздымающихся геологических образований над соседними сооружениями, где темпы вертикального роста ниже или движение отсутствует. Вокруг воздымающегося мегаблока возникает обширная область сжатий, в том числе к западу от зоны будущего эпицентра. Поскольку внешние элементы ГЭДС располагаются на кровле астеносферы и находятся друг с другом в изостатическом равновесии, их тесная взаимная укладка предопределяет взаимодействие полей горизонтальных напряжений на всех уровнях геологического разреза. При этом семейство литосферных мегаблоков, получившее мощный инициирующий импульс роста, испытывает растяжение, а деформации, которые развиваются в смежных, но неподвижных или погружающихся блоках, становятся негативной репликой процессов разуплотнения материала в воздымающихся образованиях. Такие тесные межблоковые взаимодействия подобны траектории двух концов коромысла и являются прямым следствием упомянутого выше «уравновешенного» состояния литосферных мегаблоков в ГЭДС.

Интенсивные и множественные флюидофизические (гидравлические) возмущения в несущем астеносферном слое нарушают баланс между литосферными мегаблоками и порождают специфический колебательный процесс в блоках ГЭДС. По существу, в этих формах взаимодействия литосферных блоков и астеносферного материала проявляется особый механизм пространственных колебательных движений мантийно-корового материала: каждое воздымание мегаблока сопровождается прогибанием кровли астеносферы под смежным геологическим образованием и погружением этого образования ниже его исходного состояния (т.е. до того состояния, когда был получен импульс погружения).

За этим погружением следует «взброс» третьего мегаблока вверх, вызывающий погружение четвертого и т.д., что регистрируется как цепочка деформационных импульсов с противоположными знаками. Каждый последующий импульс-реплика представляет собой уменьшенное зеркальное отображение своего предшественника, то есть в длинных рядах мегаблоков региструются последовательно сменяющие другу друга состояния растянутости и сжатости толщ, причем одна и та же направленность деформационного процесса присуща мегаблокам, разделенным между собой крупными литосферными массивами, в которых развиваются процессы противоположного знака. И каж- дый «четный» мегаблок по отношению к мегаблоку с интенсивными растяжениями испытывает деформации сжатия.

Сравнительно быстрое погружение мегаблоков, непосредственно прилегающих к будущей эпицентральной области, видимо, можно связать с эвакуацией высоконапорной газовой составляющей астеносферы из-под этих структур в верхние этажи геологического разреза. Вместе с тем из-за вязкости флюидов несущего слоя на начало таких процессов должны накладываться небольшие задержки, а также затухание импульса-реплики по мере удаления от очага будущего землетрясения. В целом, цепочка процессов всплытия и погружения геологических мегаблоков, которая генерирована инициирующим деформационным импульсом, обеспечивает «пробег» деформационного сигнала, в некоторых случаях - в глобальном масштабе.

Согласно зависимости (1), росту флюидного купола противодействуют суммарные внешние давления, а на заключительной стадии подготовки землетрясения, непосредственно перед сейсмической катастрофой, - прочностные свойства жесткого геологического материала. Именно предсейсмическому состоянию геологического блока, достигшего предела длительной прочности, вероятно, отвечает субгоризонтальный или седловидный участок деформограммы, за которым следует разрушение целостности массива. При этом, по некоторым наблюдениям, вслед за землетрясением отмечается уменьшение высотных отметок приподнятого эпицентрального блока [Shebalin, 1997].

Последнее обстоятельство дает основание предположить, что на заключительной стадии «созревания» землетрясения разрушающая роль принадлежит сильно сжатым надкритическим газам флюидного купола. После взрывоподобного разрыва в гипоцентре часть газовой компоненты, инициировавшей разрушение пород, уходит во внешнее пространство и оставляет «свободные» объемы для частичной усадки приподнятых толщ. На ведущую роль газовых составляющих в созревании сейсмического процесса указывает в своей монографии И.Л. Гуфельд [Gufeld, 2007].

Таким образом, собственно сейсмический процесс можно рассматривать как результат тесного взаимодействия двух сред: хрупких образований земной коры и астеносферных упругопластичных масс, в которых преобладают газовые компоненты. Преодолевая предел длительной прочности геологических массивов и взламывая коровые толщи, сжатые газовые массы астеносферного купола излучают мощные упругие колебания, представляющие наиболее губительную часть катастрофического процесса землетрясения. 


\section{7. ДЕФОРМАЦИОННЫЕ ТРИГГЕРЫ И ГЕНЕТИЧЕСКАЯ СВЯЗЬ ГРУПП СИЛЬНЫХ ЗЕМЛЕТРЯСЕНИЙ}

Судить об интенсивности поступления мантийного материала к очагам разгрузки в настоящее время не представляется возможным. Вместе с тем допустимо предполагать, что функционирует некоторый природный ограничитель накопления в астеносфере тяжелых флюидов, жидкостей, летучих компонентов, что делает «созревание» мощнейших землетрясений, например $\mathrm{M=8.0}$ и выше, относительно редким природным явлением. При таком «регулировочном механизме» одиночные землетрясения диапазона магнитуд $\mathrm{M}=8.0-9.0$ во многих эпизодах сейсмической жизни Земли замещаются серией землетрясений $\mathrm{M}=7.0$, которые созревают и реализуются в короткие промежутки времени в пределах пусть и очень больших, но вместе с тем ограниченных секторов планеты. Иными словами, серия землетрясений цикла скоротечной геодинамической активизации снимает упругую энергию, накапливающуюся в литосферном пространстве крупного региона Земли и способную в одноразовом порядке разрядиться как сильнейшее землетрясение. Результаты ГГД-мониторинга дают основание предполагать, что в этих случаях развиваются мощные направленные процессы воздымания и формируются критические напряжения в литосферном пространстве.

Сопоставление данных ГГД-мониторинга и сейсмологических наблюдений свидетельствует, что для разрядки каскада уже «созревших» землетрясений оказывается достаточно прохождения вдоль астеносферного слоя сильного деформационного импульса (вызванного землетрясением с магнитудой не менее $M=7.0$ ), который выполняет функции спускового механизма. Возможность триггерных сейсмических эффектов в геологической среде обсуждалась ранее [Nikolaev, Vereshchagina, 1991].

\section{8. НЕКОТОРЫЕ ПРИМЕРЫ БЫСТРЫХ ДЕФОРМАЦИОННЫХ ЭВОЛЮЦИЙ КРУПНЫХ РЕГИОНОВ ЗЕМЛИ В ПЕРИОДЫ СКОРОТЕЧНОЙ ГЕОДИНАМИЧЕСКОЙ АКТИВИЗАЦИИ}

Показательна в этом отношении геодинамическая активность и связанная с ней серия мощных землетрясений, которые были зафиксированы в восточной части Тихого океана и Андах в первой половине 2010 г.

В обширном регионе от Анд до Мексиканского залива и Карибского моря прямые исследования ГГД-поля не проводились. В рассматриваемом эпизоде сейсмической жизни крупного ареала Земли мы исходили из результатов большой серии региональных ГГД-реконструкций, которые давали ос- нование рассматривать планету как целостное деформируемое пространство с тесно связанными режимами функционирования разных частей ГЭДС. С учетом таких предпосылок выполнен анализ результатов деформационного мониторинга, который осуществлялся в пределах других, сильно удаленных друг от друга ареалов планеты.

В этом случае весьма информативными оказались результаты ГГД-мониторинга (период времени с июля 2009 г. по май 2011 г.), который систематически осуществлялся на Малом Кавказе сейсмологической службой Республики Армения и на Дальнем Востоке, в Хабаровском крае, российским предприятием «Гидроспецгеология». Кроме того, с целью анализа были привлечены доступные в сети Интернет данные гидрогеологического мониторинга, который был реализован Геологической службой Канады на западе страны.

Выполненные работы показали, что в период подготовки землетрясения на Гаити и серии сильных сейсмических событий у западного побережья Южной Америки, в Чили (землетрясение Мауле, M=8.8, 27.02.2010 г.), в сильно удаленных от рассматриваемого ареала регионах Кавказа и с отставанием от него на Дальнем Востоке, а позже в Канадских Кордильерах отмечено прохождение мощного импульса деформации, который характеризовался интенсивным разуплотнением геологических образований и завершался вырождением структур растяжения (рис. 6).

Поскольку каждое мощное землетрясение на заключительной фазе подготовки сопровождается четко выраженным деформационным импульсом, кривая De-t состояния геологических объектов на Кавказе, «накрывшая» сейсмические события в Тихом океане и Андах, оказалась результирующей сигналов, предварявших все «тихоокеанские и южно-американские» землетрясения этого времени. То же самое, очевидно, относится к импульсамрепликам, которые характеризуют деформограммы по Дальнему Востоку и Канадским Кордильерам.

Вместе с тем из приведенного графика следует, что максимум растяжений на Кавказе мог быть зафиксирован 25-26 февраля, т.е. за сутки до мощнейшего землетрясения в Андах. В то же время максимумы растяжений на Дальнем Востоке и в Канадских Кордильерах проявились существенно позже сильных землетрясений на Гаити и в Андах.

Совершенно очевидно, что эти же быстрые вариации напряженно-деформированного состояния литосферных образований должны были затронуть и геологические толщи в Мексиканском заливе, вызвав природно-техногенную катастрофу на буровой платформе Deepwater Horizon [Vartanyan, 2010]. В этом конкретном случае следует подчерк- 


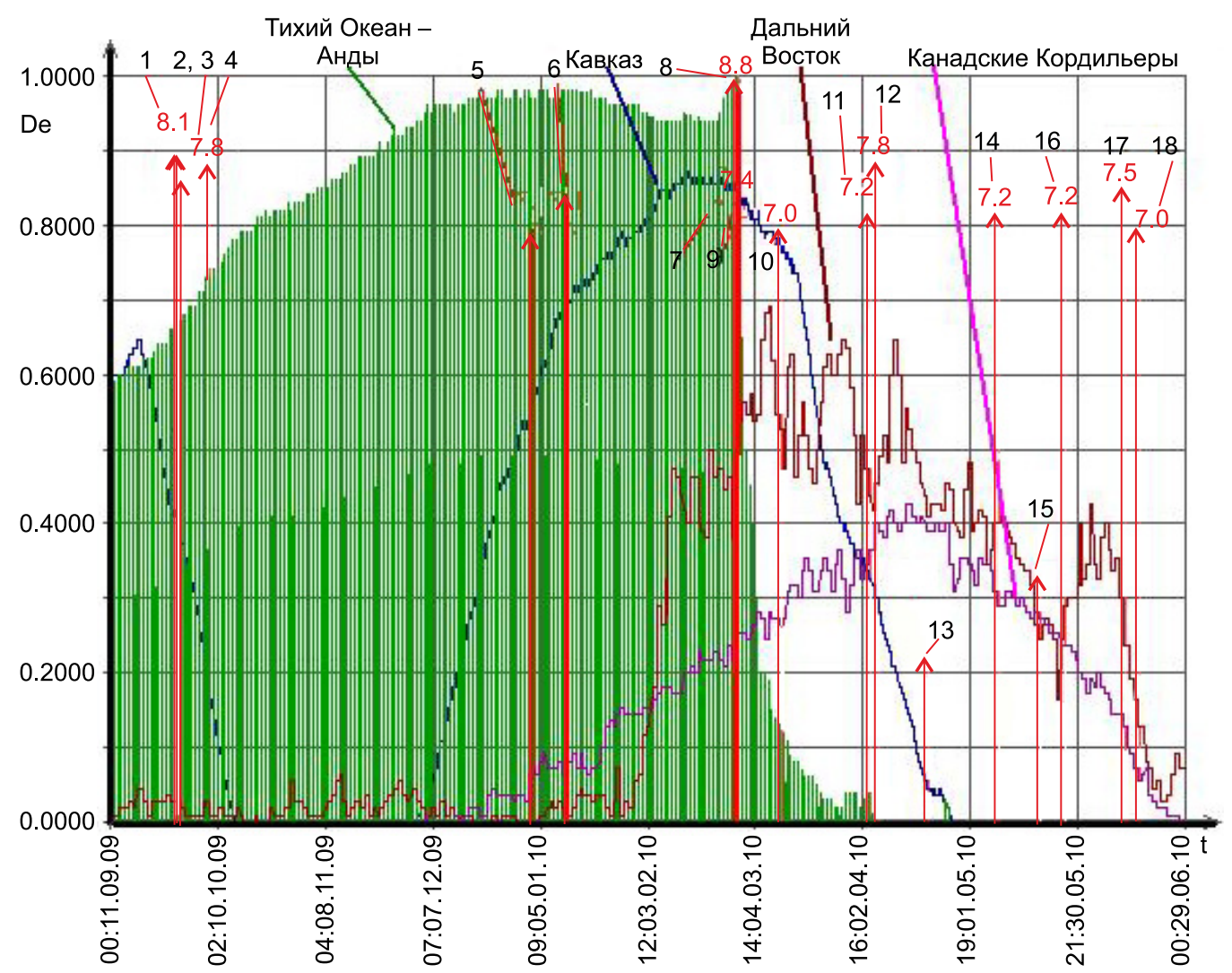

Рис. 6. Совмещенные кривые De-t по Кавказу, российскому Дальнему Востоку и Канадским Кордильерам, характеризующие реплики деформационных импульсов, которые поступали от ареалов с геодинамически активизированными процессами в Пацифике. Зеленое поле - предполагаемый деформационный импульс, генерированный в юговосточной части Тихого океана и Андах при «созревании» серии землетрясений региона. Номерами обозначены землетрясения и другие катастрофы: 1 - Самоа, 2 - Суматра, 3 - Вануату, 4 - Санта Круз, 5 - Соломоновы острова, 6 Гаити, 7 - Рюккю, 8 - Мауле (Био-Био), 9 - Мауле, 10 - Анды, 11 - Байя Калифорния (Мексика), 12 - Суматра, 13 - катастрофа Deepwater Horizon, 14 - Суматра, 15 - извержение вулкана в Гватемале, 16 - Вануату, 17 - Никобарские острова, 18 - Папуа Новая Гвинея.

Fig. 6. Combined De-t curves for the Caucasus, Russian Far East and Canadian Cordillera. The curves characterize the replicas of deformation impulses, which were received from the areas with geodynamically activated processes in the Pacific. Green field - assumed deformation impulse generated in the southeastern part of the Pacific and the Andes during the 'maturation' of the series of earthquakes in the region. Numbers indicate earthquakes and other catastrophic events: 1 - Samoa, 2 - Sumatra, 3 - Vanuatu, 4 - Santa Cruz , 5 - Solomon Islands, 6 - Haiti, 7 - Ryukkyu , 8 - Maule (Bio-Bio), 9 - Maule , 10 Andes, 11 - Bahia California (Mexico), 12 - Sumatra, 13 - Deepwater Horizon catastrophe, 14 - Sumatra, 15 - volcanic eruption in Guatemala, 16 - Vanuatu, 17 - Nicobar Islands, 18 - Papua New Guinea.

нуть факт близости координат нефтяной платформы, где 20.04.2010 г. случилась катастрофа $\left(28.44^{\circ}\right.$ с.ш., 88.21 которое произошло в акватории Мексиканского залива 10.09.2006 г.(26.32 ${ }^{\circ}$ с.ш., $86.61^{\circ}$ з.д.).

Из этих реконструкций следует, что весь регион Юго-Восточной Пацифики испытывал мощный подъем и растягивающие деформации литосферных образований, а разрядка этих нагрузок реализовалась после прохождения деформационных импульсов, поступивших со стороны Соломоновых островов (землетрясения 03.01.2010 г., $\mathrm{M}=6.6$ и $\mathrm{M}=7.1$ ). Следует подчеркнуть, что этот цикл скоротечной геодинамической активизации привел к изверже- нию вулкана Пакойя в Гватемале (27.05.2010 г.), который с 1956 г. не проявлял свою активность.

Как становится очевидным из рассмотренного материала, прохождение деформационных сигналов-реплик перед серией землетрясений могло быть прослежено также во всех регионах Земли, расположенных восточнее упомянутого обширного ареала, поэтому было бы исключительно важно рассмотреть данные, которые, возможно, имеются у соответствующих служб, изучающих геодинамические процессы в Пиренеях, на Апеннинах, на Балканах и др.

Другой характерный пример деформационных эволюций, которые практически одновременно ох- 
ватили крупные ареалы Земли, показывает развитие обстановки в период подготовки и реализации мощного Рудбар-Манджилского землетрясения (M=7.7, июнь 1990 г., Северный Иран). Эпицентр землетрясения находился в пределах хребта Эльбурс, где, следует полагать, шли мощные процессы воздымания территории и формировалась обширная структура растяжения. Наблюдения за эволюциями поля деформаций в этом регионе не выполнялись. В то же время систематические исследования ГГД-поля на специализированных сетях осуществлялись на Кавказе, в Туркмении (Копетдаг) и Казахстане (Тянь-Шань).

Деформограммы, полученные в этих регионах, дали возможность оценить масштабы ареала подготовки Рудбар-Манджилского землетрясения и проанализировать режим развития этого процесса в каждом из названных регионов. Как следует из сопоставления кривых De-t, в сейсмоподготовительном процессе принимали участие огромные литосферные массивы. Достаточно указать, например, что расстояние между крайними точками рассматриваемого ареала (условно, г. Краснодара на западе и г. Алматы - на востоке) составляет порядка 4000 км. Можно думать, что в приведенных измерениях учтены далеко не все ареалы - участники процесса. Так, в частности, с Рудбар-Манджилским землетрясением совпал резкий сигнал на деформограмме полигона Паркфилд в Калифорнии [Vartanyan, 2000, 2015; Vartanyan et al., 2002].

Как следует из приводимых деформограмм, во всех рассматриваемых регионах в период наблюдений происходили контрастные изменения состояния недр. Особенно показателен регион Центрального Кавказа, который оказался в тыльной части будущей эпицентральной области. Здесь с апреля 1990 г. проявлялись процессы резкого сжатия массивов, достигшие максимума к середине июня 1990 г. Сразу вслед за Рудбар-Манджилским землетрясением породы этого крупного региона получили мощный импульс растяжений (рис. 7).

Контрастно, по сравнению с рассмотренным режимом, развивалась деформационная обстановка в Копетдаге. Массивы Копетдага, наиболее близко располагающегося к эпицентральной области будущей сейсмической катастрофы, к началу 1990 г. испытывали интенсивные растяжения, что свидетельствует о таких же процессах в пределах хребта Эльбурс. Вместе с тем отмечается тренд постепенной деградации растяжений, причем деформограмма этого региона отличается исключительно резкими и многократными переходами от состояния сильных растяжений к столь же сильным сжатиям. Такие процессы происходили в короткие промежутки времени длительностью от нескольких суток до часов. К моменту сейсмического собы- тия массивы Копетдага испытывали значительные нагрузки сжатия. Примерно через три месяца после землетрясения в Копетдаге установился режим сильного сжатия геологических толщ. Процесс, близкий по тенденциям развития, наблюдается в Тянь-Шане.

В июне 1990 г. в рассматриваемых геологических сооружениях происходит резкая дифференциация направленности деформационных процессов, что приводит росту растяжений в Копетдаге (и, очевидно, в пределах хребта Эльбурс). При этом очень показательна реакция геологических массивов на Тянь-Шане, в Калифорнии (Паркфилд) и на Кавказе, выразившаяся в резко наступивших сжатиях толщ. Особенно контрастными были сжатия, зафиксированные в двадцатых числах июня на полигоне Паркфилд, отстоящем от эпицентра иранской катастрофы на расстоянии не менее 15 тыс. км.

Отмеченный факт дает основание говорить о высокой степени «упругости» литосферы, обеспечивающей реакцию удаленных ареалов Земли на предельные деформации коровых элементов в эпицентре будущего мощного сейсмического события (рис. 8). Даже не располагая сведениями о развитии процессов деформации в эпицентре этого иранского землетрясения, по приведенным кривым De-t можно с уверенностью говорить об интенсивном воздымании и растяжениях горных массивов региона Эльбурс - Копетдаг перед мощной сейсмической катастрофой.

Такой вывод подтверждают и внемасштабные деформационные хронопрофили, полученные для упомянутой группы регионов (рис. 9). Из анализа этих профилей следует, что изменение напряженно-деформированного состояния массивов хребта Эльбурс оказало мощное воздействие на протяженные части эндодренажной системы и, по существу, проявилось в глобальном масштабе.

Так, к началу мая 1990 г. в пределах Копетдага и Тянь-Шаня господствовали процессы растяжения, в то время как на Кавказе, находившемся к западу по отношению к району будущего эпицентра, преобладали нагрузки сжатия. Калифорния (Паркфилд) в рассматриваемый период испытывала значительные растяжения, по масштабам соизмеримые с теми, которые развивались в Копетдаге и на Тянь-Шане. Сейсмическая катастрофа 20.06.1990 г. в пределах хребта Эльбурс проявилась как резкое сжатие геологических массивов во всех наблюдаемых регионах, включая Калифорнию. В последующее время происходят множественные разнонаправленные процессы смены деформированного состояния массивов, причем Копетдаг и Тянь-Шань спустя почти три месяца после события остались в зоне сильных сжатий, в то время как Калифорния 

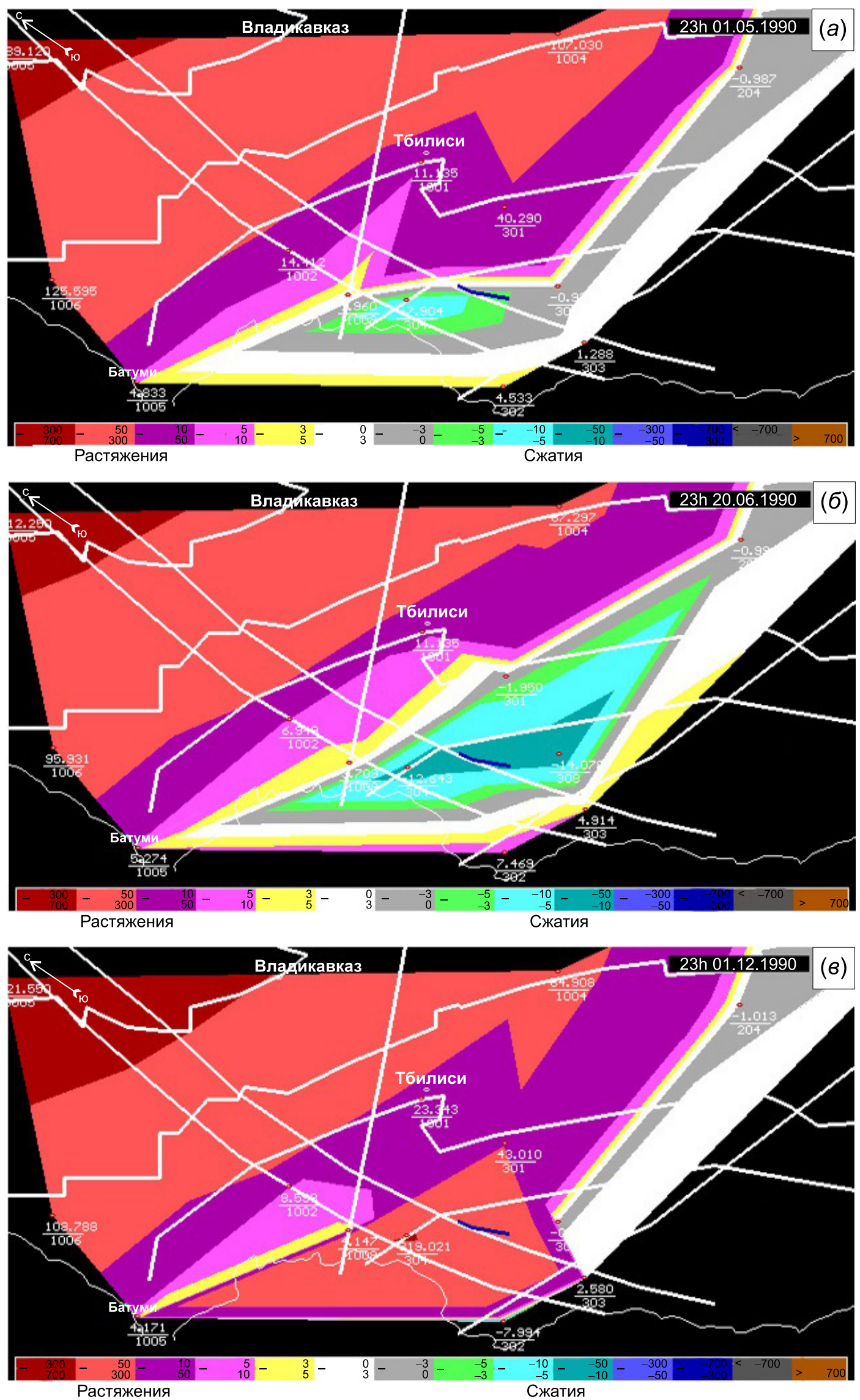

Рис. 7. Кавказский полигон ГГД-мониторинга. Карта ГГД-поля в период подготовки (01.05.1990 г.) (a), в день Рудбар-Манджилского землетрясения (20.06.1990г.) (б) и спустя 6 месяцев (01.12.1990г.) (в).

Fig. 7. The Caucasus HGD monitoring polygon. (a) - HGD map for the earthquake preparation period (01.05.1990), (6) - the day of the M 7.7 20.06.1990 Rudbar-Manjil earthquake, and ( 8 ) - six months after the earthquake (01.12.1990). 

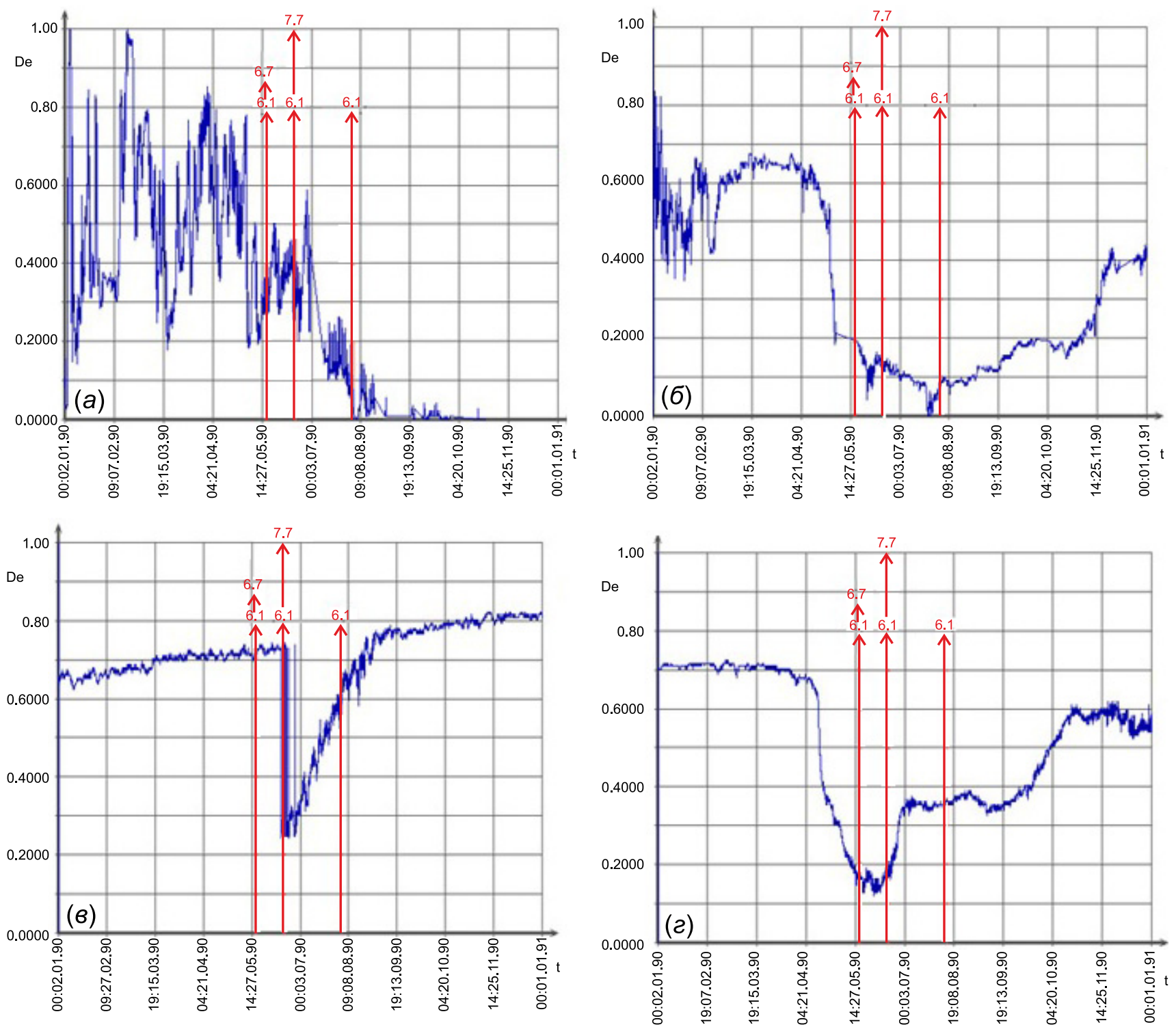

Рис. 8. Деформограммы периода подготовки и реализации землетрясения Рудбар-Манджил (Иран, М=7.7, 20.06.1990 г.) по регионам: Копетдаг (a); Тянь-Шань (б); Калифорния (в); Кавказ (2).

Fig. 8. Deformograms for the period of preparation and occurrence of the M 7.7 20.06.1990 Rudbar-Manjil earthquake (Iran) by region: (a) Kopetdag; (б) Tien Shan; ( 8 ) California; (2) Caucasus.

достаточно резко, а Кавказ более плавно вновь испытали процессы растяжения.

\section{9. ЗАКЛЮЧЕНИЕ}

Закономерности функционирования ГГД-поля, в сочетании с известными современной геологии важнейшими чертами строения планеты, являются основой для суждения о доминантной роли глубинных флюидов в геодинамической жизни Земли. При этом астеносфера и глобальная эндодренажная система планеты в создании предпосылок для проявления большинства землетрясений высоких энергий играют определяющую роль.
Основные выводы сводятся к следующему.

Процессы высокотемпературной переработки глубинного вещества сформировали обширную флюидосферу, продукты которой, массированно поступающие к внешним частям планеты, оказывают определяющее воздействие на становление современной геологической оболочки, гидро- и атмосферы Земли. Эти объемы флюидов участвуют в энергомассообменных процессах с внешним пространством, а также оказывают динамическое воздействие на положение верхней границы (кровли) астеносферного слоя.

Астеносфера является объемной мембраной между пластичной и высоконагретой мантией и жесткой и «холодной» земной корой. Совокупное 


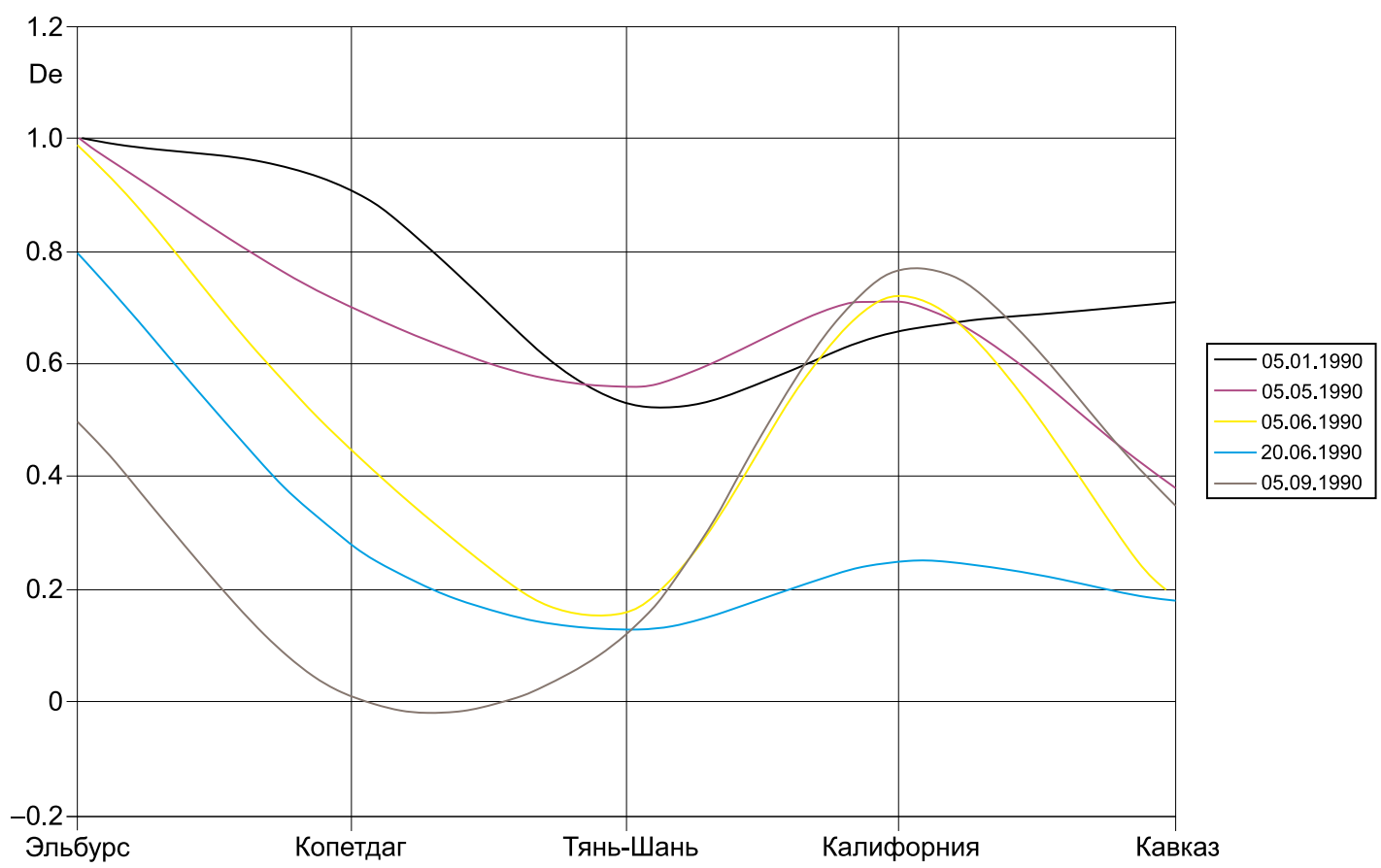

Рис. 9. Внемасштабные деформационные хронопрофили по линии Эльбурс - Копетдаг - Тянь-Шань - Калифорния Кавказ в период подготовки и после Рудбар-Манджилского землетрясения (M=7.7, 20.06.1990 г.). Значения величин Dе по ареалу Эльбурса приняты предположительно.

Fig. 9. Non-scale deformation chronoprofiles along the Elburs - Kopetdag - Tien Shan - California - Caucasus line during the preparation period and after the M 7.7 20.06.1990 Rudbar-Manjil earthquake. Values De for the Elburz area are assumed.

воздействие внешних и глубинных факторов на текущее состояние матрицы (например, изменение баланса давлений, рост или падение температур флюида) способно сильно менять состояние и несущие свойства астеносферы и создавать предпосылки для развития опасных геодинамических процессов в геологических образованиях.

Важнейшим регулятором разгрузки огромных флюидных масс на поверхность и близповерхностные части планеты выступает специфическая мегаструктура - глобальная эндодренажная система, базовой частью которой является астеносферный слой. К ГЭДС приурочено подавляющее большинство аномальных геохимических и геофизических зон Земли, на этот слой проецируется большинство сейсмических поясов планеты.

Сейсмические катастрофы являются опосредованным результатом поступления в астеносферу мантийного вещества. Эти процессы приводят к вытеснению вверх группы геологических мегаблоков, что создает направленные нагрузки на глобальное поле напряжений и, как следствие, вызывает быстрые изменения регионального поля деформаций. С наиболее деформационно-нагруженными участками литосферного пространства связаны гипоцентры сильных землетрясений.

«Созреванию» землетрясения предшествует длительный процесс направленных растяжений крупных литосферных мегаблоков, который завершается резким сжатием, разрушением сплошности массивов и излучением упругой энергии.

«История» деформационного развития литосферных толщ, особенно на заключительных этапах созревания сильных землетрясений, четко прослеживается по характерным импульсам, регистрируемым в процессе региональных гидрогеодеформационных исследований, и дает представление об исключительно высокой чувствительности специфичного слоя «кора - астеносфера» к внешним (включая техногенные) нагрузкам.

Глубинные возмущения регистрируются в приповерхностной части литосферного пространства как быстрые вариации глобального ГГД-поля. Прослежена специфичная форма миграции деформационного импульса, которую обеспечивает цепочка последовательных скоротечных всплытий и погружений мегаблоков ГЭДС. Этот процесс можно фиксировать в глобальном масштабе как «пробег» деформационного импульса.

Быстрые вариации структуры ГГД-поля позволяют отслеживать циклы скоротечной геодинамической активизации. При этом прослеживаются триггерные эффекты, вызывающие каскады геодинамически «родственных» сейсмических событий.

В прикладном плане рассмотренные свойства литосферного пространства, включая прохождение 
вдоль планеты сравнительно низкоскоростных, но отчетливо регистрируемых деформационных сигналов-импульсов, могут стать надежной основой для эффективного функционирования системы глобального деформационного (геодинамического) мониторинга, а также для средне- и краткосрочного прогноза катастрофических и сильных землетрясений.

\section{0. ЛИТЕРАTУPA / REFERENCES}

Avdalovich V.S., 1972. Kanandinskaya volcano-tectonic structure in the south-eastern part of the Tunguska syneclise. Bulletin of the Moscow University. Series 4: Geology (5), 95-99 (in Russian) [Авдалович B.C. Канандинская вулкано-тектоническая структура в юго-восточной части Тунгусской синеклизы // Вестник Московского университета. Серия 4: Геология. 1972. № 5. С. 95-99].

Avdalovich V.S., 1973. Kanandinskaya group of volcanic apparatus of the Nizhnyaya Tunguska River middle reaches basin. Bulletin of the Moscow University. Series 4: Geology (2), 106-109 (in Russian) [Авдалович В.С. Канандинская группа вулканических аппаратов в бассейне среднего течения реки Нижняя Тунгуска // Вестник Московского университета. Серия 4: Геология. 1973. № 2. С. 106-109].

Avsyuk Yu.N., 1996. Tidal Forces and Natural Processes. Nauchny Mir, Moscow, 188 p. (in Russian) [Авсюк Ю.Н. Приливные силы и природные процессы. М.: Научный мир, 1996. 188 с.].

Avsyuk Yu.N., Sobisevich L.E., Sobisevich A.L., 2002. Model of the tidal evolution of the Earth-Moon system and tectonic activity of the Earth. In: Catastrophic processes. Moscow, p. 13-118 (in Russian] [Авсюк Ю.Н., Собисевич Л.Е., Собисевич А.Л. Модель приливной эволюции системы Земля - Луна и тектоническая активность Земли // Катастрофические процессы. М., 2002. С. 13-118].

Bell J.S., Babcock E.A., 1986. The stress regime of the Western Canadian Basin and implications for hydrocarbon production. Bulletin of Canadian Petroleum Geology 34 (3), 364-378.

Bell J.S., McCallum R.E., 1990. In situ stress in the Peace River Arch area, western Canada. Bulletin of Canadian Petroleum Geology 38 (1), 270-281.

Borell B., 2009. Deep structure images under Hawaii. Naturenews December 2009.

Bredehoeft J.D., 1967. Response of well-aquifer systems to earth tides. Journal of Geophysical Research 72 (12), 3075-3087. https://doi.org/10.1029/JZ072i012p03075.

Carey S.W., 1988. Theories of the Earth and Universe: A History of Dogma in the Earth Sciences. Stanford University Press, Stanford, 436 р. [Русский перевод: Кэри У. В поисках закономерностей развития Земли и Вселенной. М.: Мир, 1991. 447 с.].

Christensen O.W., 1994. Hydrogeological measurement of regional volume strain down to 3 kilometres depth. In: 9th International seminar on earthquake prognostics. San Jose, Costa Rica, p. 1-15.

Cox J.W., 1983. Long axis orientation in elongated boreholes and correlation with rock stress data. In: SPWLA Twenty fourth annual logging symposium transactions (June 27-30, 1983). Vol. 1. Calgary, Alberta, Canada, p. 1-17.

Discoveries and Inventions, 1983. Publication of discoveries registered in the National Register of discoveries in the USSR. In: Official Bulletin of the USSR State Committee for Inventions and Discoveries, No. 46, p. 3 (in Russian) [Открытия и изобретения. Публикация об открытиях, зарегистрированных в Государственном реестре открытий СССР // Официальный бюллетень Государственного комитета СССР по делам изобретений и открытий. 1983. № 46. С. 3].

Dobretsov N.L., Kirdyashkin A.G., 1994. Deep Geodynamics. Siberian Branch of RAS Publishing House, Novosibirsk, 299 p. (in Russian) [Добрецов Н.Л., Кирдяшкин А.Г. Глубинная геодинамика. Новосибирск: Изд-во СО РАН, 1994. 299 c.].

Fyfe W.S., Price N.J., Thompson A.B. (Eds.), 1978. Fluids in the Earth's Crust: Their Significance in Metamorphic, Tectonic and Chemical Transport Processes. Developments in Geochemistry, vol. 1. Elsevier, Amsterdam, 383 p.

Gough D.I., Bell J.S., 1981. Stress orientations from oil-well fractures in Alberta and Texas. Canadian Journal of Earth Sciences 18 (3), 638-645. https://doi.org/10.1139/e81-056.

Gufeld I.L., 2007. Seismic Process. Physicochemical Aspects. CNIIMash, Moscow, 160 p. (in Russian) [Гуфельд И.Л. Сейсмический процесс. Физико-химические аспекты. М.: ЦНИИМаш, 2007. 160 с.].

Hofmann A.W., 1997. Mantle geochemistry: the message from oceanic volcanism. Nature 385 (6613), 219-229. https://doi.org/10.1038/385219a0.

Hsieh P.A., Bredehoeft J.D., Rojstaczer S.A., 1988. Response of well aquifer systems to earth tides: Problem revisited. Water Resources Research 24 (3), 468-472. https://doi.org/10.1029/WR024i003p00468.

Kalinin V.A., Rodkin M.V., Tomashevskaya I.S., 1989. Geodynamic Effects of Physicochemical Transformations in Solid Medium. Nauka, Moscow, 157 p. (in Russian) [Калинин В.А., Родкин М.В., Томашевская И.С. Геодинамические эффекты физико-химических превращений в твердой среде. М.: Наука, 1989. 157 с.].

Khain V.E., Lomize M.G., 2005. Geotectonics and Fundamentals of Geodynamics. KDU, Moscow, 560 p. (in Russian) [Хаин В.E., Ломизе М.Г. Геотектоника с основами геодинамики. М.: КДУ, 2005. 560 с.]. 
Kirdyashkin A.A., Dobretsov N.L., Kirdyashkin A.G., Gladkov I.N., Surkov N.V., 2005. Hydrodynamic processes associated with plume rise and conditions for eruption conduit formation. Geologiya i Geofizika (Russian Geology and Geophysics) 46 (9), 869-885.

Kopnichev Yu.F., Sokolova I.N., 2003. Mantle fluids and strong crustal earthquakes. In: Stress-strain state and seismicity of the lithosphere. Proceedings of the Meeting. Geo, Novosibirsk, p. 63-67 (in Russian) [Копничев Ю.Ф., Соколова И.Н. Мантийные флюиды и сильные коровые землетрясения // Напряженно-деформированное состояние и сейсмичность литосферы: Материалы совещания. Новосибирск: Гео, 2003. С. 63-67].

Krasnyi L.I., 2000. Ascending depth and near-surface structures and associated minerageny. Otechestvennaya Geologiya (Russian Geology) (6), 23-28 (in Russian) [Красный Л.И. Восходящие глубинные и близповерхностные структуры и связанная с ними минерагения // Отечественная геология. 2000. № 6. С. 23-28].

Lambeck K., Johnson P., 1998. The viscosity of the mantle: evidence from analyses of glacial-rebound phenomena. In: I. Jackson (Ed.), The Earth's mantle: composition, structure and evolution. Cambridge University Press, New York, p. 461-502.

Letnikov F.A., 2002. Degassing of the Earth as a global process of self-organization. In: Earth degassing: geodynamics, geofluids, oil and gas. Proceedings of the International Conference in Memory of Academician P.N. Kropotkin. GEOS, Moscow, p. 6-7 (in Russian) [Летников Ф.А. Дегазация Земли как глобальный процесс самоорганизации // Дегазация Земли: геодинамика, геофлюиды, нефть и газ: Материалы Международной конференции памяти академика П.Н. Кропоткина. М.: ГЕОС, 2002. С. 6-7].

Letnikov F.A., Dorogokupets P.I., 2001. The role of superdeep fluid systems of the earth's core in endogenic geological processes. Doklady Earth Sciences 378 (4), 500-502.

Lithgow-Bertelloni C., Silver P.G., 1998. Dynamic topography, plate driving forces and the African superswell. Nature 395 (6699), 269-272. https://doi.org/10.1038/26212.

Liu B., Liang Y., 2017. The prevalence of kilometer-scale heterogeneity in the source region of MORB upper mantle. Science Advances 3 (11), e1701872. https://doi.org/10.1126/sciadv.1701872.

Magnitsky V.A., 1985. Modern vertical movements of the Earth's crust: the 'paradox' of high velocities. Zemlya Vselennaya (Earth and the Universe) (4), 10-14 (in Russian) [Магницкий В.A. Современные вертикальные движения земной коры: «парадокс» больших скоростей // Земля и Вселенная. 1985. № 4. С. 10-14].

Marakushev A.A., 2002. Geological consequences of the Earth crust degassing. In: Earth degassing: geodynamics, geofluids, oil and gas. Proceedings of the International conference in memory of academician P.N. Kropotkin. GEOS, Moscow, p. 8-10 (in Russian) [Маракушев A.A. Геологические следствия дегазации земного ядра // Дегазация Земли: геодинамика, геофлюиды, нефть и газ: Материалы Международной конференции памяти академика П.Н. Кропоткина. М.: ГЕОС, 2002. С. 8-10].

Markhinin E.K., 1967. The Role of Volcanism in the Formation of the Crust (Case the Kuril Island Arc). Nauka, Moscow 256 p. (in Russian) [Мархинин Е.К. Роль вулканизма в формировании земной коры (на примере Курильской островной дуги). М.: Наука, 1967. 256 с.].

Melchior P., 1966. The Earth Tides. Pergamon Press, Oxford, 458 р. [Русский перевод: Мельхиор П. Земные приливы. М.: Мир, 1968. 482 с.].

Milanovsky E.E., 1968. Modern Tectonics of the Caucasus. Nedra, Moscow, 483 p. (in Russian) [Милановский Е.Е. Новейшая тектоника Кавказа. М.: Недра, 1968. 483 с.].

Milanovsky E.E., 1978. Some regularities of tectonic development and volcanism of the Earth in the Phanerozoic (problems of pulsation and expansion of the Earth). Geotectonics (6), 3-16 (in Russian) [Милановский Е.Е. Некоторые закономерности тектонического развития и вулканизма Земли в фанерозое (проблемы пульсации и расширения Земли) // Геотектоника. 1978. № 6. С. 3-16].

Milanovsky E.E., 1995. Pulsations of the Earth. Geotectonics (5), 3-24 (in Russian) [Милановский Е.Е. Пульсации Земли // Геотектоника. 1995. № 5. С. 3-24].

Molodensky M.S., 1953. Elastic tides, free nutation, and some problems of the Earth structure. In: Proceedings of the Geophysical Institute, No. 19 (146), p. 1-146 (in Russian) [Молоденский М.С. Упругие приливы, свободная нутация и некоторые вопросы строения Земли // Труды Геофизического института. 1953. № 19 (146). C. 1-146].

Nikolaev A.V., Vereshchagina G.M., 1991. On the initiation of earthquakes by earthquakes. Doklady AN SSSR 318 (2), 320-324 (in Russian) [Николаев А.В., Верещагина Г.М. Об инициировании землетрясений землетрясениями // Доклады АН СССР. 1991. Т. 318. № 2. С. 320-324].

Pariysky N.N., 1960. Earth tides and the internal structure of the Earth. Vestnik AN SSSR (6), 61-69 (in Russian) [Пaрийский Н.Н. Земные приливы и внутреннее строение Земли // Вестник АН СССР. 1960. № 6. С. 61-69].

Pavlenkova N.I., 2001. The structure of the Earth's crust and upper mantle and global geotectonics. In: Tectonics of the Neogene: general and regional aspects. Proceedings of the XXXIV Tectonic Meeting. Vol. 2. GEOS, Moscow, p. 94-97 (in Russian) [Павленкова Н.И. Структура земной коры и верхней мантии и глобальная геотектоника // Тектоника неогея: общие и региональные аспекты: Материалы XXXIV тектонического совещания. М.: ГEOC, 2001. T. 2. C. 94-97]. 
Pavlenkova N.I., 2004. Results of seismic studies of the upper mantle in Russia. In: Seismic studies of the Earth's crust. Publishing House of SB RAS, Novosibirsk, p. 237-243 (in Russian) [Павленкова Н.И. Результаты сейсмических исследований верхней мантии на территории России // Сейсмические исследования земной коры. Новосибирск: Изд-во СО РАН, 2004. С. 237-243].

Polubarinova-Kochina P.Ya., 1952. A Theory of Groundwater Motion. Gostekhizdat, Moscow, 674 p. (in Russian) [Полубаринова-Кочина П.Я. Теория движения грунтовых вод. М.: Гостехиздат, 1952. 674 с.].

Prouteau G., Scaillet B., Pichavant M., Maury R., 2001. Evidence for mantle metasomatism by hydrous silicic melts derived from subducted oceanic crust. Nature 410 (6825), 197-200. https://doi.org/10.1038/35065583.

Rice J.R., 1992. Fault stress states, pore pressure distributions, and the weakness of the San Andreas fault. Chapter 20. In: B. Evans, T.-F. Wong (Eds.), Fault mechanics and transport properties of rocks. International Geophysics Series, vol. 51. Academic Press, New York, p. 475-503.

Rice J.R., Cleary M.P., 1976. Some basic stress diffusion solutions for fluid-saturated elastic porous media with compressible constituents. Reviews of Geophysics 14 (2), 227-241. https://doi.org/10.1029/RG014i002p00227.

Rice J.R., Rudnicki J.W., 1979. Earthquake precursory effects due to pore fluid stabilization of a weakening fault zone. Journal of Geophysical Research: Solid Earth 84 (B5), 2177-2193. https://doi.org/10.1029/JB084iB05p02177.

Shchelkachev V.N., 1946. Main equations of fluid motion in an elastic porous medium. Doklady AN SSSR 52 (2), 103-106 (in Russian) [Щелкачев B.H. Основные уравнения движения упругой жидкости в упругой пористой среде // Доклады АН СССР. 1946. Т. 52. № 2. С. 103-105].

Shebalin N.V., 1997. Strong Earthquakes. Academy of Mining Sciences Publishing House, Moscow, 541 p. (in Russian) [Шебалин Н.В. Сильные землетрясения. М.: Изд-во Академии горных наук, 1997. 541 с.].

Stacey F.D., Davis P.V., 2008. Physics of the Earth. Cambridge University Press, New York, 513 p.

Van der Hilst R.D., Widiyantoro S., Engdahl E.R., 1997. Evidence for deep mantle circulation from global tomography. Nature 386 (6625), 578-584. https://doi.org/10.1038/386578a0.

Vartanyan G.S., 1968. The role of regional metamorphism processes in the formation of certain types of mineral waters and their provinces. Bulletin of Moscow Society of Naturalists, Geological section 18 (3), 99-105 (in Russian) [Вартанян Г.С. Роль процессов регионального метаморфизма в формировании некоторых типов минеральных вод и их провинций // Бюллетень Московского общества испытателей природы. Отдел геологический. 1968. Т. 18. № 3. С. 99-105].

Vartanyan G.S., 1977. Deposits of Carbonate Waters of Mountain-Folded Regions. Nedra, Moscow, 284 p. (in Russian) [Вартанян Г.С. Месторождения углекислых вод горно-складчатых регионов. М.: Недра, 1977. 284 с.].

Vartanyan G.S., 1979a. A method for studying the stress state of a massif. Russian Patent No. 776278. (in Russian) [Вартанян Г.С. Способ изучения напряженного состояния массива. Российский патент № 776278. 1979].

Vartanyan G.S., 1979b. A method for earthquake prediction. Russian Patent No. 791021. (in Russian) [Вартанян Г.C. Способ прогнозирования землетрясений. Российский патент № 791021. 1979].

Vartanyan G.S., 1993. Role of hydrogeodeformation field in the evolution of the underground hydrosphere. Otechestvennaya Geologiya (Russian Geology) (1), 91-95 (in Russian) [Вартанян Г.C. Роль гидрогеодеформационного поля в эволюции подземной гидросферы // Отечественная геология. 1993. № 1. С. 91-95].

Vartanyan G.S., 1995. The hydrogeodeformation field in studying geodynamic mechanisms. Otechestvennaya Geologiya (Russian Geology) (4), 29-37 (in Russian) [Вартанян Г.С. Гидрогеодеформационное поле в исследованиях механизмов геодинамики // Отечественная геология. 1995. № 4. С. 29-37].

Vartanyan G.S., 1999. The regional system of geodynamic monitoring: sustainable development of seismic-prone regions. Otechestvennaya Geologiya (Russian Geology) (2), 37-45 (in Russian) [Вартанян Г.C. Региональная система геодинамического мониторинга и проблема устойчивого развития государств сейсмоопасных провинций мира // Отечественная геология. 1999. № 2. С. 37-45].

Vartanyan G.S., 2000. The fluidosphere and endodrainage system of the Earth as key factors in geological evolution. Otechestvennaya Geologiya (Russian Geology) (6), 14-22 (in Russian) [Вартанян Г.C. Флюидосфера и эндодренажные системы Земли как ведущие факторы геологической эволюции // Отечественная геология. 2000. № 6. C. 14-22].

Vartanyan G.S., 2001. Regional system of geodynamic monitoring: sustainable development of seismic-prone regions. In: UN Forum on Urban Geology in Asia and the Pacific (Bangkok, 2001). Bangkok, p. 355-373.

Vartanyan G.S., 2003. Geodynamic processes in the fluidosphere and some of their consequences. Otechestvennaya Geologiya (Russian Geology) (2), 44-50 (in Russian) [Вартанян Г.C. Геодинамические процессы во флюидосфере и некоторые их следствия // Отечественная геология. 2003. № 2. С. 44-50].

Vartanyan G.S., 2004. The Earth's fluidosphere. In: L.I. Krasny, O.V. Petrov, B.A. Blyuman (Eds.), The Planet Earth: an encyclopedic guide. Vol. 1. Tectonics and geodynamics. VSEGEI, Saint Petersburg, p. 144-149 (in Russian) [Bapтанян Г.С. Флюидосфера Земли // Планета Земля: энциклопедический справочник. Т. 1. Тектоника и геодинамика / Ред. Л.И. Красный, О.В. Петров, Б.А. Блюман. СПб.: ВСЕГЕИ, 2004. С. 144-149]. 
Vartanyan G.S., 2006. The Earth's endodrainage system and seismicity: Prospects of monitoring. Otechestvennaya Geologiya (Russian Geology) (1), 41-52 (in Russian) [Вартанян Г.C. Эндодренажная система Земли и сейсмичность: перспективы мониторинга // Отечественная геология. 2006. № 1. С. 41-52].

Vartanyan G.S., 2007. Hydraulic foreshock - ultra-short seismic precursor. Otechestvennaya Geologiya (Russian Geology) (4), 59-66 (in Russian) [Вартанян Г.C. Гидравлический форшок - сверхкраткосрочный сейсмический предвестник // Отечественная геология. 2007. № 4. С. 59-66].

Vartanyan G.S., 2008a. Some deformation mechanisms of the operation of the Earth's endodrainage system and seismicity. Otechestvennaya Geologiya (Russian Geology) (2), 18-27 (in Russian) [Вартанян Г.C. Некоторые деформационные механизмы функционирования эндодренажной системы Земли и сейсмичность // Отечественная геология. 2008. № 2. С. 18-27].

Vartanyan G.S., 2008b. Strain images of some earthquakes and short-term earthquake prediction. Otechestvennaya Geologiya (Russian Geology) (4), 68-74 (in Russian) [Вартанян Г.С. Деформационные образы некоторых землетрясений и краткосрочный сейсмический прогноз // Отечественная геология. 2008. № 4. С. 68-74].

Vartanyan G.S., 2010. Regional geodynamic monitoring system for ensuring safety in geological and exploratory production of oil and gas. Izvestiya, Atmospheric and Oceanic Physics 46 (8), 952-964. https://doi.org/10.1134/ S0001433810080049.

Vartanyan G.S., 2013. The global endo-drainage system: Prospects of seismic prediction. Izvestiya, Atmospheric and Oceanic Physics 49 (7), 745-759. https://doi.org/10.1134/S0001433813070074.

Vartanyan G.S., 2014. Fast deformation cycles in the lithosphere and catastrophic earthquakes: Was it possible to prevent the Fukushima tragedy? Izvestiya, Atmospheric and Oceanic Physics 50 (8), 805-823. https://doi.org/ $10.1134 / \mathrm{S} 0001433814080088$.

Vartanyan G.S., 2015. Geodynamic Catastrophes and Their Forecast (Endodrainage of the Earth, Deformation, Seismicity). Geoinformmark, Moscow, 258 p. (in Russian) [Вартанян Г.С. Геодинамические катастрофы и их прогноз (эндодренаж Земли, деформации, сейсмичность). М.: Геоинформмарк, 2015. 258 с.].

Vartanyan G.S., 2016. Strain anatomy of two seismic catastrophes: geophysical weapon or the natural events? Science and Technological Developments 95 (2), 3-28 (in Russian) [Вартанян Г.С. Стрейн-анатомия двух сейсмических катастроф: геофизическое оружие или природные явления? // Наука и технологические разработки. 2016. T. 95. № 2. C. 3-28].

Vartanyan G.S., Bredehoeft J.D., Roelloffs E., 1991. Hydrogeologic methods of investigating tectonic stresses. Sovetskaya Geologiya (Soviet Geology) (9), 3-12 (in Russian) [Вартанян Г.С., Бредехоефт Дж., Роэлоффс Э. Гидрогеологические методы исследований тектонических напряжений // Советская геология. 1991. № 9. С. 3-12].

Vartanyan G.S., Kristensen O.V., Gosk E., Tsukuda E., 2002. A new regional method for predicting strong earthquakes. Otechestvennaya Geologiya (Russian Geology) (1), 3-15 (in Russian) [Вартанян Г.С., Кристенсен О.В., Госк Э., Цукуда Э. Региональный метод краткосрочного прогноза сильных землетрясений // Отечественная геология. 2002. № 1. С. 3-15].

Vartanyan G.S., Kulikov G.V., 1982. Hydrogeodeformational field of the Earth. Doklady AN SSSR 262 (2), 310-314 (in Russian) [Вартанян Г.С., Куликов Г.В. Гидрогеодеформационное поле Земли // Доклады АН СССР. 1982. T. 262. № 2. C. 310-314].

Vartanyan G.S., Kurennoy V.V., Ostrovsky L.A., Sheko A.I., Shpak A.A., 1997. The problems of study and assessment of the geoenvironmental state in Russia. In: Z. Zhang, E.F.J. de Mulder, T. Liu, L. Zhou (Eds.), Proceedings of the 30th International Geological Congress (4-14 August, 1996), vols. 2 and 3. Utrecht, p. 83-93.

Vartanyan G.S., Popov E.A., Voleysho V.O. et al., 1985. Guidelines for Organization and Performance of Hydrogeological Observations in a Specialized Regional Network for Prediction of Strong Earthquakes. VSEGINGEO, Moscow, $41 \mathrm{p}$. (in Russian) [Вартанян Г.С., Попов Е.А., Волейшо В.О. и др. Методические указания по организации и проведению гидрогеологических наблюдений на специализированной региональной сети в целях прогноза сильных землетрясений. М.: ВСЕГИНГЕО, 1985. 41 с.].

Vartanyan G.S., Stazhilo-Alekseev S.K., Zaltsberg E.A., 2013. Hydrogeodeformation monitoring: prospects for seismic forecasting. Otechestvennaya Geologiya (Russian Geology) (6), 61-70 (in Russian) [Вартанян Г.C., СтажилоАлексеев С.К., Зальцберг Э.А. Гидрогеодеформационный мониторинг: перспективы сейсмического прогноза // Отечественная геология. 2013. № 6. С. 61-70].

Wolfe C.J., Bjarnason I.T., Van Decar J.C., Solomon S.C., 1997. Seismic structure of the Iceland mantle plume. Nature 385 (6613), 245-247. https://doi.org/10.1038/385245a0.

Wolfe C.J., Solomon S.C., Laske G., Collins J.A., Detrick R.S., Orcutt J.A., Bercovici D., Hauri E.H., 2009. Mantle shear-wave velocity structure beneath the Hawaiian hot spot. Science 326 (5958), 1388-1390. https://doi.org/10.1126/ science.1180165.

Yassir N.A., Bell J.S., 1994. Relationships between pore pressure, stresses, and present-day geodynamics in the Scotian Shelf, offshore Eastern Canada. AAPG Bulletin 78 (12), 1863-1880.

Zhao D., Kanamori H., Negishi H., Wiens D., 1996. Tomography of the source area of the 1995 Kobe earthquake: evidence for fluids at the hypocenter? Science 274 (5294), 1891-1894. https://doi.org/10.1126/science.274. 5294.1891.

Zoback M.L., Zoback M., 1980. State of stress in the conterminous United States. Journal of Geophysical Research: Solid Earth 85 (B11), 6113-6156. https://doi.org/10.1029/JB085iB11p06113. 


\section{СВЕДЕНИЯ ОБ АВТОРE । INFORMATION ABOUT AUTHOR}

\section{Генрих Сенекеримович Вартанян}

докт. геол.-мин. наук, профессор

Lithosphere Strain Kinetics Inc.

2-217 Valhalla Inn Rd. Toronto, Ontario M9B 6C3, Canada

凶 e-mail: gayanav@hotmail.com; gvartanyan@lskinc.ca

\section{Genrikh S. Vartanyan}

Doctor of Geology and Mineralogy, Professor

Lithosphere Strain Kinetics Inc

2-217 Valhalla Inn Rd. Toronto, Ontario M9B 6C3, Canada 